\title{
Confirmed detection of Palaeogene and Jurassic orbitally-forced sedimentary cycles in the depth domain using False Discovery Rates and Bayesian probability spectra
}

\author{
Graham P. Weedon \\ Met Office, Maclean Building, Benson Lane, Crowmarsh Gifford, Wallingford, Oxfordshire, OX10 8BB, UK \\ graham.weedon@metoffice.gov.uk.
}

\begin{abstract}
It has been common practice to assume that power spectral backgrounds in cyclostratigraphy conform to a first-order autoregressive (AR1) model. Vaughan et al. (2011, Paleoceanography) argued that an unbiased approach to fitting the spectral backgrounds, as well as adjustment of confidence levels for multiple frequency testing, should be mandatory during the search in the depth domain for significant spectral peaks. To address these requirements Smoothed Window Averaging to find spectral backgrounds are combined with False Discovery Rates (FDR) for setting confidence levels and were applied to time series from seven Oligocene and Jurassic formations. Bayesian probability spectra provide an alternative method for detecting regular cyclicity. Pre-whitening the linearly detrended time series prior to calculation of Bayesian probabilities avoids confounding effects due to red noise.

In all seven formations there are sub-sections associated with spectral peaks exceeding the $5 \%$ FDR, in four formations they even exceed the $0.01 \%$ FDR. Elevated Bayesian probability at the same frequencies as these significant power spectral peaks, supports the detection of regular cyclicity. This prevalence of detections conflicts with the assertion of Vaughan et al. (2011) that "almost certainly the vast majority of cycle detections ... in the stratigraphy literature are false." In previous publications spectral peaks exceeding the standard $95 \%$ level were considered significant so very high confidence levels were not reported. Nevertheless, the examples re-studied demonstrate that pre-Neogene cyclostratigraphic time series do indeed contain regular cycles most likely linked to orbital-forcing.
\end{abstract}

Keywords: Bayesian probability spectra, Cyclostratigraphy, False detection rates, Spectral analysis

\section{Detección confirmada de ciclos sedimentarios de forzamiento orbital en el Paleogeno y Jurásico en depth domain, usando Tasas de Hallazgos Falsos $y$ espectros de probabilidad bayesiana}

RESUMEN

De manera habitual, se ha supuesto que los fondos espectrales de potencia en clicloestratigrafía se ajustan a un modelo autorregresivo de primer orden (AR1). Vaughan et al. (2011, Paleoceanography) señaló que un método de ajuste de fondos espectrales más flexible y sin sesgo, además de ajuste de niveles de confianza para pruebas de frecuencias múltiples, debería ser obligatorio en la búsqueda de picos espectrales significativos en depth domain. Para complacer estos requerimientos, se combinan ajustes Smoothed Window Averaging (Promedio de Ventana Suavizada) para encontrar fondos espectrales con False Discovery Rates (FDR, Tasa de Hallazgos Falsos) para establecer niveles de confianza, y se aplican a series temporales cicloestratigráficas previamente publicadas de siete formaciones oligocenas y jurásicas. De manera adicional, los espectros de probabilidad bayesiana aportan un método alternativo de detección de ciclicidad periódica.

En las siete formaciones hay sub-secciones asociadas a los picos espectrales que exceden el 5\% FDR, en cuatro formaciones incluso exceden el $0.01 \%$ FDR. Alta probabilidad bayesiana, en las mismas frecuencias de estos picos espectrales de potencia significativos, apoya la inferencia de que se ha detectado ciclicidad periódica. La prevalencia de detección confirmada de ciclicidad periódica entra en conflicto con la afirmación de Vaughan et al. (2011): "casi con total certeza la gran mayoría de las detecciones de ciclos ... en la literatura sobre estratigrafía son falsas". En publicaciones previas, picos espectrales que exceden el nivel estándar del 95\% eran considerados significativos, por lo que niveles de confianza muy elevados no fueron publicados. Sin embargo, los ejemplos reanalizados aquí demuestran que series temporales de cicloestratigrafía pre-neogena contienen ciclos periódicos, muy probablemente asociados a forzamiento orbital.

Palabras clave: probabilidad bayesiana, cicloestratigrafía, ration de detección falsa, análisis espectral. 
Graham P. Weedon, 2020. Confirmed detection of Palaeogene and Jurassic orbitally-force... Boletín Geológico y Minero, 131 (2): $207-230$

\section{VERSIÓN ABBREVIADA EN CASTELLANO}

\section{Introducción}

Al menos para estudios cicloestratigráficos, Walther Schwarzacher fue el primero en publicar niveles de confianza en espectros de potencia relativos a fundos espectrales ajustados, y no usando gráficos de barras con intervalos de confianza para estimaciones espectrales individuales (figura 8.6 en Schwarzacher, 1975). Subsiguientemente, fondos espectrales fueron modeladas como derivadas de ruido autorregresivo de primer orden (AR1) (Priestley, 1981; Weedon, 2003). El ajuste de fondos espectrales para localizar niveles de confianza llevó, indirectamente, al método Mann and Lees (1996) para el ajuste de fondos AR1 "robustos". Sin embargo, las limitaciones del ajuste de AR1 robustas fueron criticadas más adelante (Vaughan et al., 2011; Meyers, 2012). $A$ veces, los fondos $A R 1$ robustos generan fondos espectrales demasiado bajas en las menores frecuencias, desencadenando en identificaciones incorrectas de picos espectrales como distinguibles estadísticamente del fondo (i.e. un "error Tipo I").

Además de la suposición inadecuada de que los fondos espectrales en cicloestratigrafía se ajustan a un modelo AR1, Vaughan et al. (2011) identificó otros problemas de los métodos actuales de análisis espectral. Los niveles de confianza espectral estándar son establecidos usando un distribución $\chi^{2}$ que es adecuada para testear una frecuencia espectral individual predeterminada buscando evidencias de regularidad superpuesta en el ruido de fondo. No obstante, en depth domain los investigadores buscan normalmente signos de regularidad a lo largo de todas las frecuencias espectrales disponibles. Vaughan et al. (2011) apuntó que los niveles de confianza usados deben de ser ajustados para permitir este testeo múltiple y así evitar errores Tipo I.

Las distintas limitaciones del análisis espectral de estratos en depth domain del dominio llevaron a la siguiente afirmación: "La alta tasa de ciclos espurios significa que casi con total certeza la gran mayoría de detecciones de ciclos derivadas de datos estratigráficos muestreados espacialmente (casos en la sección 5) en la literatura sobre estratigrafía son falsas." (pp11-12, Vaughan et al., 2011). A ésto seguía: "Esto limita severamente la utilidad de detecciones publicadas para demostrar periodicidades de Milankovitch en sedimentos pre-neógenos, y su uso para establecer una geocronología firme o investigar la dinámica del sistema solar a largo plazo." (p12, Vaughan et al., 2011).

Los argumentos técnicos de Vaughan et al. (2011) concernientes al análisis espectral han de ser cuidadosamente considerados por la comunidad cicloestratigráfica. Aquí yo debato el uso de: a) el método de promedio de ventana suavizada para localizar fondos espectrales empíricamente, en lugar de usando un ajuste de AR1 robusta; b) tasas de hallazgos falsos (FDR) para minimizar errores Tipo I mientras se controlan los errores Tipo II (i.e. descarte inadecuado de un pico espectral tan significativo); y c) espectros de probabilidad bayesiana como método alternativo para la detección de la presencia de ciclos periódicos. Estos métodos han sido aplicados en ejemplos de estratos paleógenos (oligocenos) y jurásicos publicados en los últimos treinta años por el autor, de los que los ejemplos terrestres fueros examinados con Walther durante mi defensa de tesis doctoral en Oxford en 1987.

\section{Métodos}

Para evitar distorsión de las frecuencias más bajas por la "pérdida" de potencia debido a una tendencia, en todos los casos las tendencias son inicialmente eliminadas de manera lineal de los datos. En lugar de suponer que la distribución espectral resulta de ruido AR1, el promedio de ventana suavizada (SWA) se usa para ajuste de fondos (Weedon et al., 2019).

El testeo estándar de picos en espectros de potencia usando distribuciones $\chi^{2}$ permite la varianza (grados de libertad) de las estimaciones espectrales, pero está diseñado para comprobar una frecuencia individual. Para estimaciones espectrales no correlacionadas encontradas en periodogramas a partir del uso de ventanas senciIlas ("single data tapers"), hay dos métodos de corrección disponibles para ajustar los niveles de confianza; las correcciones de Šidàk y de Bonferroni (Abdi, 2007). Ambas correcciones proporcionan un método para calcular un nivel de confianza nuevo con una cierta tasa de falsas alarmas (e.g. 5\%), y así permitir testeo múltiple de todas las frecuencias.El nivel de confianza revisado se llama False Alarm Level (FAL, Nivel de Falsas Alarmas).

Weedon et al. (2019) introdujeron y describieron en detalle el uso de False Discovery Rates (FDR, Tasa de Hallazgos Falsos) para cicloestratigrafía, cuyos pioneros en literatura sobre estadística fueron Bejamini y Hoch- 
berg (1995). Debido a la correlación de estimaciones espectrales, FDR es adecuado para tests de siginificancia de picos espectrales en espectros de potencia. El valor del método FDR radica en que los errores Tipo I están controlados y al mismo tiempo las probabilidades de errores Tipo II se minimizan. En la Fig. 1 y todas las figuras subsiguientes el estándar 99\% y los niveles FDR se ilustran relativos a los ajustes SWA de fondos.

Además, Weedon et al. (2019) introdujeron el uso de espectros de probabilidad bayesiana en cicloestratigrafía. El modelo puesto a prueba es que las series temporales consistían en ruido blanco con un único ciclo periódico superpuesto. Las probabilidades bayesianas indican la probabilidad de que los datos observados se correspondan con el modelo. Sin embargo, si el modelo puesto a prueba es una mala elección, entonces cualquier alta probabilidad que pueda ser encontrada puede, potencialmente, resultar de factores de confusión (Bretthorst, 1988). Para evitar que la probabilidad bayesiana esté sesgada por la presencia de ruido rojo (browniano), las series temporales con tendencias eliminadas linealmente han sido "pre-blanqueadas" con anterioridad al afinamiento de datos ("data tapering") y la transformada de Lomb-Scargle.

\section{Resultados y Conclusiones}

Las Figuras 2 y 3 muestran las localizaciones de dónde fueron obtenidas las series temporales cicloestratigráficas y las fotografías en trabajo de campo. Además de análisis de datos de isótopos de oxígeno del Pleistoceno Inferior (Fig. 4), se han testeado series temporales d siete formaciones litostratigráficas del Oligoceno y del Jurásico en busca de evidencias de ciclicidad periódica en la depth domain (Figs. 5-12). En cuatro formaciones los picos de potencia espectral excedieron el 0.01\% FDR. Los datos de una de estas cuatro localizaciones en "Blue Lias Formation" del Jurásico Inferior de Reino Unido (Southam Quarry) alcanzaron un pico espectral que sólo pasa el 10\% FDR. En todos los demás casos, los espectros contenían al menos un pico excediendo del 5\% FDR. Todas las formaciones alcanzaron alta probabilidad bayesiana en apoyo de picos de potencia espectral excediendo el $5 \%$ FDR.

Estos resultados no son coherentes con la afirmación de Vaughan et al., (2011): "casi con total certeza la gran mayoría de las detecciones de ciclos ... en la literatura sobre estratigrafía son falsas". Dado que los métodos de proceso utilizados representan una aprobación de las mejoras técnicas promovidas por Vaughan et al. (2011; 2015), ¿por qué su afirmación no es ratificada? A pesar del hecho de que los métodos utilizados para la eliminación de tendencias, la localización de fondos y el establecimiento de los niveles de confianza, eran inadecuados en la literatura publicada según Vaughan et al. $(2011 ; 2015)$, no se puede concluir que no hubiesen sido analizadas ciclicidades periódicas significativas reales. Los ejemplos descritos en este artículo prueban, en la opinión del autor, que estudios clicloestratigráficos de estratos paleógenos y jurásicos publicados con anterioridad incluían conclusiones sólidas. Lo cual no demuestra que éste fuese el caso en todas las publicaciones. Ciertamente, se necesita la publicación de datos que puedan ser re-examinados usando los métodos más rigurosos descritos por Vaughan et al. (2011).

Aún existe una asignatura pendiente en cuanto a la adecuación de testeo múltiple. Se trata de la selección de subsecciones de datos para el análisis. Vaughan et al. (2011) se posicionó a favor de la validez de generar espectros de potencia para la series temporales cicloestratigráficas completas sin permitir no-estacionalidad. Sin embargo, se sabe que los análisis de datos no-estacionarios degradan la probabilidad de detección de ciclicidad periódica en depth domain (e.g. Weedon, 2003) independientemente de la utilización de métodos espectrales apropiados. El análisis espectral sólo puede proporcionar una descripción relevante de la distribución de varianza según la frecuencia si los datos analizados son estacionarios y ergódicos (Priestley, 1981). Sin embargo, la subdivisión de datos podría ser considerada como una forma de "minería de datos" por los escépticos y, en consecuencia, debería ser permitido el testeo múltiple implícito. Desafortunadamente, la forma de aplicar estas adecuaciones no es obvia. La resolución de esta cuestión requerirá trabajo futuro.

No obstante, en los casos de Rosso Ammonitico Lombardo (Toarciano), la formación de Morbio Inferior (Pliensbachiano medio) que se muestra en la Fig. 8 y la formación de Morbio Superior (Pliensbachiano Superior - resultados no publicados), los datos completos han sido analizados. En los tres casos al menos un pico espectral excede el $0.01 \%$ FDR. Dado que en estos casos no se han seleccionado sub-secciones de datos, no se requiere adecuación para testeo múltiple y se confirma la periodicidad en depth domain. 


\section{Introduction}

Although he reviewed my first paper (Weedon, 1986), I first met Walther Schwarzacher in 1987 as the external examiner for my doctoral defence at the University of Oxford. I was prepared to be deferential in my approach to the viva (held "behind closed doors"), but it became obvious within the first five minutes that both he and Jim Kennedy (the internal examiner) wanted me to provide a rigorous justification of my work. There followed three hours or so of detailed discussion of the sedimentology of the Blue Lias Formation and the use of Walsh spectral analysis applied to several other Jurassic formations as well as an Oligocene (Palaeogene) section. I never got to know Walther very well, but we met repeatedly during the nineteen eighties and nineteen nineties at several meetings in Britain as well as in Tubingen and Perugia. I always found him to be friendly and supportive to people using time series analysis for cyclostratigraphy.

For cyclostratigraphic studies at least, Walther was the first to show confidence levels on power spectra relative to a fitted spectral background rather than illustrating confidence interval bars for individual spectral estimates (figure 8.6 of Schwarzacher, 1975). The example he introduced showed a quadratic fit to the spectral background. Spectral backgrounds were later generally modelled as derived from first-order autoregressive (AR1) noise.

Fitting spectral backgrounds to localise confidence levels led indirectly to the Mann and Lees (1996) method for fitting "robust" AR1 backgrounds. Lag-1 autocorrelation $\left(\rho_{1}\right)$ is typically determined by the Pearson's $r$ correlation of the time series with itself offset by one time step. The $\rho_{1}$ in turn determines the shape, especially the average slope, of spectral backgrounds. Over-estimation of $\rho_{1}$ leads to a steeper spectral background and often a lower chance of detecting a genuine spectral peak in the low frequencies (a "Type II error"). Robust AR1 fitting was introduced because, if genuine regular cycles are superimposed on pure AR1 noise, then the calculation of the lag-1 autocorrelation is biased to be too high (Mann and Lees, 1996). However, the robust AR1 fitting approach has limitations, for which it was later criticized (Vaughan et al., 2011; Meyers 2012; Crampton et al., 2018).

Aside from the use of inappropriately fitted spectral backgrounds in cyclostratigraphy, especially reliance on the sole use of the AR1 model of noise inherent in the Mann and Lees (1966) method, Vaughan et al. (2011) identified another problem with current methods of spectral analysis. Standard spectral confidence levels are set using a $\chi^{2}$ (chi-squared) distribution which is appropriate when testing a single pre-determined spectral frequency for evidence for regularity. However, in the absence of firm dating for time domain analyses or when analysing time series in the depth domain, researchers typically test all available spectral frequencies. Vaughan et al. (2011) noted that the confidence levels need to be adjusted to allow for multiple testing to avoid Type I errors.

Unfortunately, by minimizing Type I errors there is inevitably an increased likelihood of falsely rejecting spectral peaks as significant (Type II errors, Kemp, 2016). Furthermore, it has been argued that distortions of the depth/time relationship caused by random variations in accumulation rates mean that the adjustments to confidence levels advocated by Vaughan et al. (2011) are inappropriate (Hinnov et al., 2016). The statistical power of a significance test results from the competing influences of Type I and II errors. As explained later, the approach taken here is to regardType II errors (failing to detect regular cyclicity) as always preferable to Type I errors (incorrectly claiming detection of regular cycles).

The various limitations of spectral analysis of strata in the depth domain led to the following assertion: "The high rate of spurious cycles means that almost certainly the vast majority of cycle detections directly derived from spatially-sampled stratigraphic data (cases in section 5) in the stratigraphy literature are false." (pp11-12, Vaughan et al., 2011). This was followed by: "This severely limits the usefulness of published detections for demonstrating Milankovitch periodicities in pre-Neogene sediments, and using them to establish a firm geochronology or investigate long-term solar system dynamics." (p12, Vaughan et al., 2011).

The technical points made by Vaughan et al. (2011) concerning spectral analysis need to be carefully considered by the cyclostratigraphic community. Here methods used for detection of regular sedimentary cycles in the depth domain, adopted by Weedon et al., 2019, are designed to address the issues they raised. These methods have been applied to Palaeogene (Oligocene) and Jurassic strata published over the last thirty years by the author, the terrestrial examples of which were discussed with Walther during my doctoral viva. This paper is designed to help test the assertion of Vaughan, et al. (2011) that: "almost certainly the vast majority of cycle detections ... in the stratigraphy literature are false".

\section{Methods}

\section{A) Power spectral estimation and background fitting}

To avoid distortion of the lowest frequencies by “leakage" of power due to a trend, in all cases the data are 
first linearly detrended (Weedon, 2003). Aside from the linear trends, note that no other low-frequency variations in the data are removed. Vaughan et al. (2015) showed that removal of low-frequency variations, aside from a linear trend, requires subjective decisions and leads to biasing of the shape of the spectral background. Effectively such pre-processing in addition to linear detrending represents high-pass filtering which necessitates revised testing of significance of low frequency spectral peaks analogous to adjusting significance levels for orbital tuning (Proistosescu et al., 2012). To minimize "periodogram leakage" a split cosine taper is applied to the first and last $5 \%$ of the detrended data (Priestley, 1981). The Lomb-Scargle transform derived from the PERIOD algorithm of Press et al. (1992) is applied to generate periodogram estimates as it is designed for analysis of regularly or irregularly spaced data. The periodogram estimates are smoothed to yield spectral estimates with eight degrees of freedom (Weedon et al., 2019).

Instead of assuming that the spectral background results from AR1 noise the smoothed window averaging (SWA) method is used for background fitting (Weedon et al., 2019). If the spectral background conforms to white noise or a power law, alternative methods should be used to find the spectral background. In outline, the SWA method involves first selecting a range of odd-numbered window sizes (e.g. ranging from 11 to 99 spectral estimates per window). Given a particular window width, the averages of the spectral estimates are determined for each successive non-overlapping window. It is critical that the averaging uses windows that do not overlap. If the windows overlapped the resulting spectral background would tend to be too low at low frequencies and too high at high frequencies the bias often encountered with robust AR1 fitting.

Next the window averages are interpolated linearly. Then alternative possible linear or quadratic fits are tested on the ends of the spectrum (i.e. for the lowestand highest-frequency intervals that lie outside the region with linearly interpolated averages). For each alternative end fit the root mean squared error (RMSE) is determined against the original spectral estimates. The end fits that produce the smallest RMSE are selected. The overall RMSE for the selected window size is determined given the linearly interpolated window averages plus the best end fits. The whole process is repeated for the full range of window widths. The best fit is judged using the lowest overall RMSE across all tested window widths. Finally, the fitted values are smoothed slightly so that gentle curves replace the piece-wise linear fit with the smoothing constrained so that overall the RMSE is not increased by more than 1\% (figure 3 of Weedon et al., 2019).
As an example of using SWA fitting a pure AR1 pseudo cyclostratigraphic time series has been created with 500 values spaced at $2.5 \mathrm{~cm}$ (Fig. 1). The AR1 time series is based on gaussian distributed random numbers generated using the RAN1 and GASDEV algorithms of Press et al. (1992) with a lag-1 autocorrelation $\left(\rho_{1}\right)$ of 0.8 . In Fig. 1 to the right of the time series, the power spectrum is shown at the top using linear power to indicate the concentrations of variance according to frequency. Underneath the logarithm of the power is plotted against frequency so that the background fitting can be seen. On the logarithmic spectral panel, the background expected for pure AR1 data with $\rho_{1}=0.8$ is shown in orange. For comparison the SWA fit is shown in grey. The raw AR1 spectrum and the SWA spectral fits are very close to each other apart from the very lowest of frequencies (lowest 5\%). On the other hand, the robust AR1 fit (blue) based on the method of Mann and Lees (1996) is substantially lower than the other fits at the low frequencies (lowest 20\%).

A second pseudo time series was also generated, this time by adding a regular cycle with a wavelength of $0.5 \mathrm{~m}$ to the pure AR1 data (standard deviation of pure AR 1 series $=1.5733$, standard deviation of added sinusoid $=0.7078$, see right hand time series in Fig. 1). Despite the added regular cycle, the resulting time series looks similar to the original pure AR1 noise data. The presence of the regular cyclicity has very little effect on the raw AR1 and SWA background fits, but the robust AR1 fit is raised compared to the prior spectrum except at the lowest frequencies. Note that SWA fitting involves use of simple averaging and not medians since the null model is that the spectrum consists of noise only. Since averages rather than medians are used potentially the SWA averages might be biased too high at the frequency of a very large spectral peak associated with a genuine regular cycle. The resulting bias in SWA fitting could cause an increase in likelihood of the false rejection of a spectral peak as significant (Type II error). Nevertheless, a Type II error is considered preferable to a Type I error (Weedon et al., 2019). As shown by the cyclostratigraphic data examples discussed later, a big advantage of the SWA method is that it adapts to spectral backgrounds that depart from the shape due to pure AR1 noise (thereby addressing the first of Vaughan et al's 2011 problems).

\section{B) Confidence levels}

Standard testing of peaks on power spectra using chi-squared distributions allows for the variance (through the degrees of freedom) of the spectral 

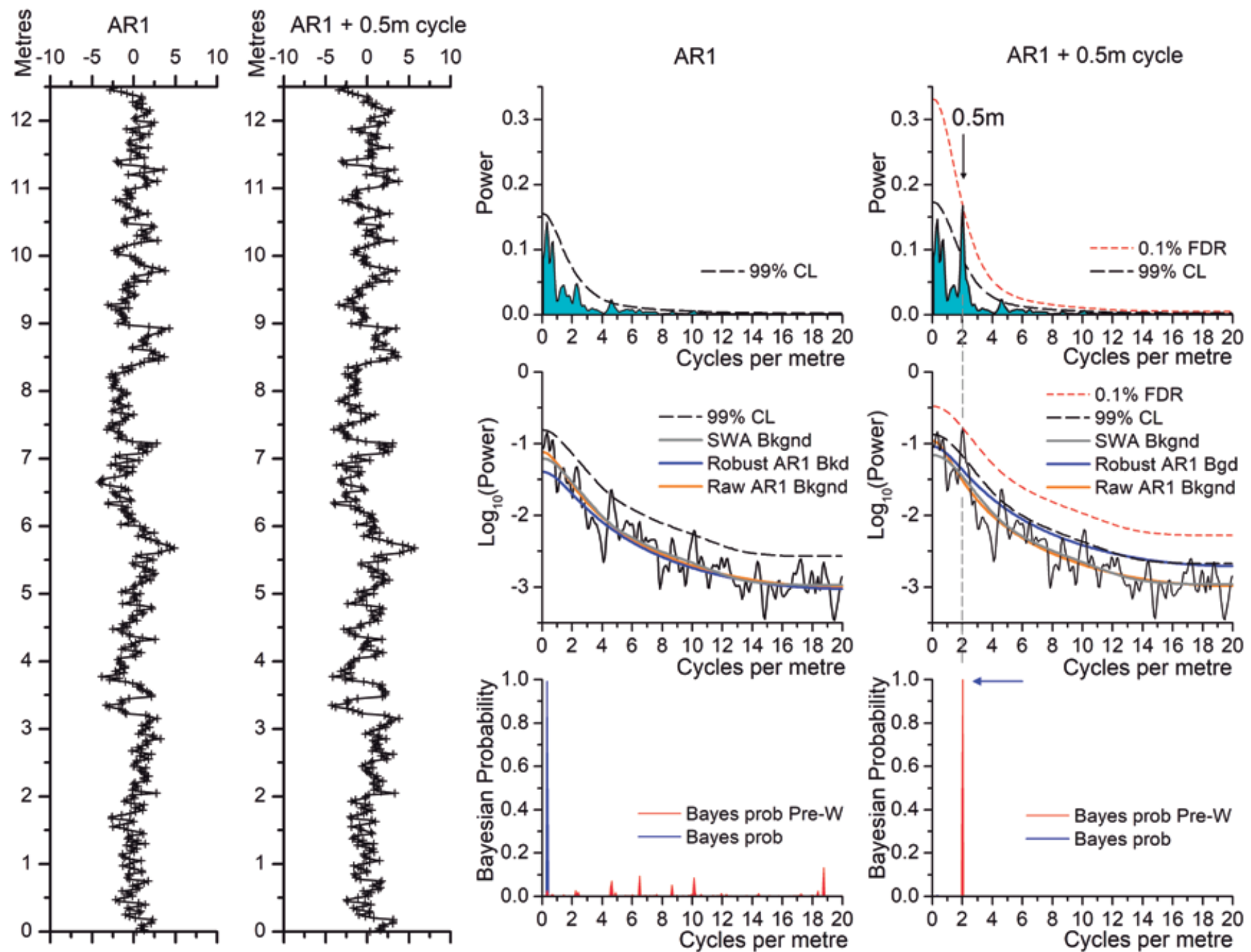

Figure 1. Left: Pseudo time series constructed from pure AR1 noise and from AR 1 noise plus a sine wave with wavelength $0.5 \mathrm{~m}$. Right: Power spectra (upper right), Log power spectra (middle right) and Bayesian probability spectra (bottom right) associated with the time series shown on the left. The Log power spectra have the fitted backgrounds illustrated: SWA (grey), robustly fitted AR1 (blue) and Raw AR1 background (orange). $\mathrm{CL}=$ Confidence level; Bkgnd/Bkd = Background; Bayes prob pre-W = Bayesian probability for pre-whitened data.

Figura 1. Izquierda: Pseudo series temporales construidas a partir de ruido de AR1 puras y a partir de ruido de AR1 más una onda sinusoidal de longitude de onda $0.5 \mathrm{~m}$. Derecha: Espectros de potencia (arriba), espectros de potencia en escala logarítmica (medio) y espectros de probabilidad bayesiana (abajo) asociados con las series temporales mostradas a la izquierda. Los espectros de potencia en escala logarítmica muestran los ajustes de fondos: SWA (gris), ajuste robusto AR1 (azul) y ajuste Raw AR1 (naranja). CL = Nivel de confianza; Bkgnd/ $B k d=$ Fondo; Bayes prob pre- $W=$ Probabilidad bayesiana para los datos pre-blanqueados.

estimates, but is designed for testing the power at a single frequency. For uncorrelated spectral estimates found in periodograms from use of single data tapers there are two methods available for adjusting confidence levels: the Šidàk and the Bonferroni corrections (Abdi, 2007). Both corrections provide a way to calculate a new confidence level with a certain rate of false alarms (e.g. $5 \%$ ) in order to allow for multiple testing of all frequencies. The revised confidence level is called the False Alarm Level (FAL).
Hinnov et al. (2016) and Kemp (2016) provided suggestions for adjusting for multiple frequency testing in cyclostratigraphy. Crampton et al. (2018) included use of False Discovery Rates (FDR, introduced by statisticians Benjamini and Hochberg, 1995) for adjusting for multiple testing in their evaluation of power spectra of graptoloid species turnover rates through geological time. Weedon et al. (2019) were apparently the first to apply FDR to power spectra in cyclostratigraphy. FDR is appropriate for testing the significance of spectral peaks in power spectra as allowance can 
made for the correlation of spectral estimates. The value of the FDR method is that Type I errors are controlled and at the same time the chances of Type II errors are minimized. The algorithm, as described by Miller et al. (2011), requires converting the spectral estimates to variance ratios. The corresponding $p$ values are determined from the variance ratios from a chi squared table given the degrees of freedom of the spectral estimates. The $p$ values are then ranked. After selecting an appropriate FDR level, the ranked $p$ values are tested against a reference level ( $j$-alpha level of Miller et al., 2011). Separately from the degrees of freedom, and as part of the calculation of the reference level, the "CN factor" is used to allow for the correlation of spectral estimates (Hopkins et al., 2002; Weedon et al., 2019).

In Fig. 1 and all subsequent figures the standard $99 \%$ confidence levels (uncorrected for multiple testing) plus the FDR confidence levels are shown relative to the SWA background fits. With 250 frequencies available, even for this case of pure AR1 noise, one would expect 2 or 3 (average 2.5) spectral estimates to exceed the $99 \%$ confidence level in Fig. 1. Indeed there are two spectral peaks exceeding the $99 \%$ confidence level at about 4.5 and 10 cycles per metre. On the other hand, no estimates pass the lowest FDR level tested (10\% FDR). In the case of the time series composed of AR1 noise plus $0.5 \mathrm{~m}$ cycles, the $0.1 \%$ FDR level is exceeded at the frequency of the regular cycles.

Kemp (2006) suggested that in order to balance the minimization of both Type I and Type II errors standard confidence levels of $99.0 \%$ to $99.9 \%$ are required. Conversely the FDR method operates by first controlling Type I errors and then finding the optimum confidence level that minimizes Type II errors. The characteristics of the data define the FDR levels (Benjamini and Hochberg, 1995). Hence, the same FDR level (e.g. 5\%) corresponds to different standard confidence levels in different datasets. For the examples discussed in the Results section, the 5\% FDR adopted as the minimum standard for confident detection here, corresponds to a range of chi-squaredderived confidence levels of between $99.96861 \%$ for the Blue Lias data at Lavernock and $99.98701 \%$ for the magnetic susceptibility data from the Kimmeridge Clay (i.e. higher than 99.9\%).

\section{C) Bayesian probability spectra}

Weedon et al. (2019) also introduced the use of Bayesian probability spectra for cyclostratigraphy. In that case the periodogram values used for generating standard power spectral estimates were re-scaled to a Student's $t$ distribution and normalised by an unbiased estimate of the total variance. The specific method described was designed by Gregory (2005) for Lomb-Scargle periodogram values as employed here. The model tested is that the time series consists of white noise $\left(\rho_{1}=0.0\right)$ with a single regular cycle superimposed. The Bayesian (posterior) probabilities indicate the likelihood that the observed data correspond to the model. However, if the model tested is a poor choice then high probabilities could potentially result from confounding factors (Bretthorst, 1988).

Bayesian probability spectra are illustrated in Fig. 1 based on two forms of data processing. For the pure AR1 time series the Bayesian probability has been calculated exactly as described by Weedon et al. (2019) and is shown in blue. This indicates a significant regular cycle at the frequency of the largest low frequency peak. Since the data consist of pure AR 1 noise, this result demonstrates that the strong red noise (large $\rho_{1}$ ) means that, compared to the white noise model being tested, the lowest, large amplitude spectral peak appears to be highly significant (despite the standard power spectra showing that there are no components exceeding the $5 \%$ FDR). In this case testing for a strong regular cycle in the presence of white noise is not appropriate and the comparison of the probability distribution with the results of the standard spectral analysis was informative.

In the case of the pseudo time series consisting of AR1 noise plus $0.5 \mathrm{~m}$ cycles the Bayesian probability based on the processing by Weedon et al. (2019) has a single peak probability of 0.9930 at the frequency of the regular cycles (the top of the probability spectrum is indicated by the blue horizontal arrow in Fig. 1). Therefore, if a sufficiently large amplitude regular component is present in the data, then whether the background noise is red rather than white does not affect the associated Bayesian probability spectrum.

On the other hand, the use of Bayesian probability spectra was introduced in order to provide an independent test of the results of standard power spectra (Weedon et al., 2019). In order to be sure that the Bayesian probability is not biased by the presence of red noise, the linearly detrended time series have been "pre-whitened" prior to data tapering and the Lomb-Scargle transform (Weedon, 2003). After setting the first pre-whitened value $(X p w(1))$ to 0.0 , the remaining values are calculated using:

$$
X p w(t+1)=r_{1} X(t+1)-X(t), t=1 \text { to } N-1
$$

where $t$ denotes the time step of the Noriginal time series values $(X(t))$. The value of $\rho_{1}$ is simply calculated as the Pearson's $r$ correlation of the time series with itself offset by one time step. 


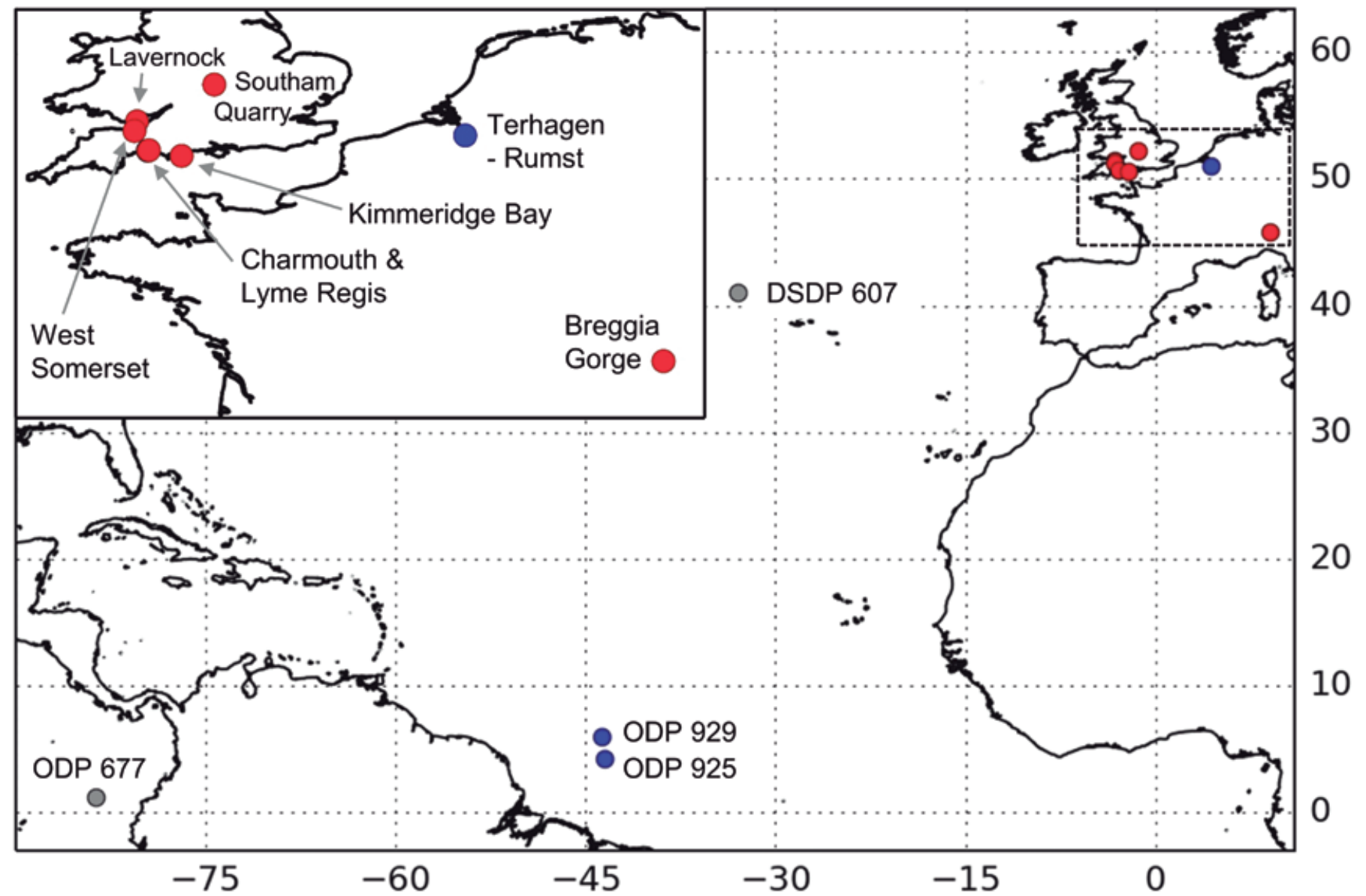

Figure 2. Location map of the oceanic drilling sites and terrestrial exposures providing the cyclostratigraphic time series analysed later. Location points are grouped by colour into Lower Pleistocene (grey); Lower Oligocene (blue) and Jurassic (red).

Figura 2. Mapa de localizaciones de ubicaciones de perforación oceánicas y exposiciones terrestres que aportan las series temporales analizadas más adelante. Los puntos indicativos de localización están agrupados en colores: Pleistoceno Inferior (gris), Oligoceno Inferior (azul) y Jurásico (rojo).

The Bayesian probability spectra calculated using the pre-whitened detrended time series are shown in red in Fig. 1 and in the subsequent spectral figures. For the pure AR1 pseudo time series as expected there is no clear concentration of probability at any particular frequency and the highest probability is just 0.132 . In contrast, for the AR 1 plus $0.5 \mathrm{~m}$ cycles the Bayesian probability reaches 0.9997 .

\section{Results}

If the assertions of Vaughan et al. (2011) quoted in the Introduction are right, then, due to flawed spectral analysis, most published depth-domain cycle detections should be regarded as the result of Type I errors and therefore spurious. In the following, detection of regular cyclicity in the depth domain is considered to require one or more power spectral peaks exceeding at least the 5\% FDR. The Bayesian analyses are provided as independent tests for the presence of at least one scale of regular cyclicity. The linear detrending and spectral procedures applied are considered to have addressed the concerns of Vaughan et al. (2011). However, if their assertion is right, then in most cases examined here there will be a lack of detection of regular cyclicity in the depth domain.

The location of the sections providing the depth domain time series that have been analysed are shown in Fig. 2 with colour coding: grey for Lower Pleistocene, blue for Oligocene and red for Jurassic. Figure 3 illustrates the terrestrial Oligocene strata and most of the Jurassic sections studied. 

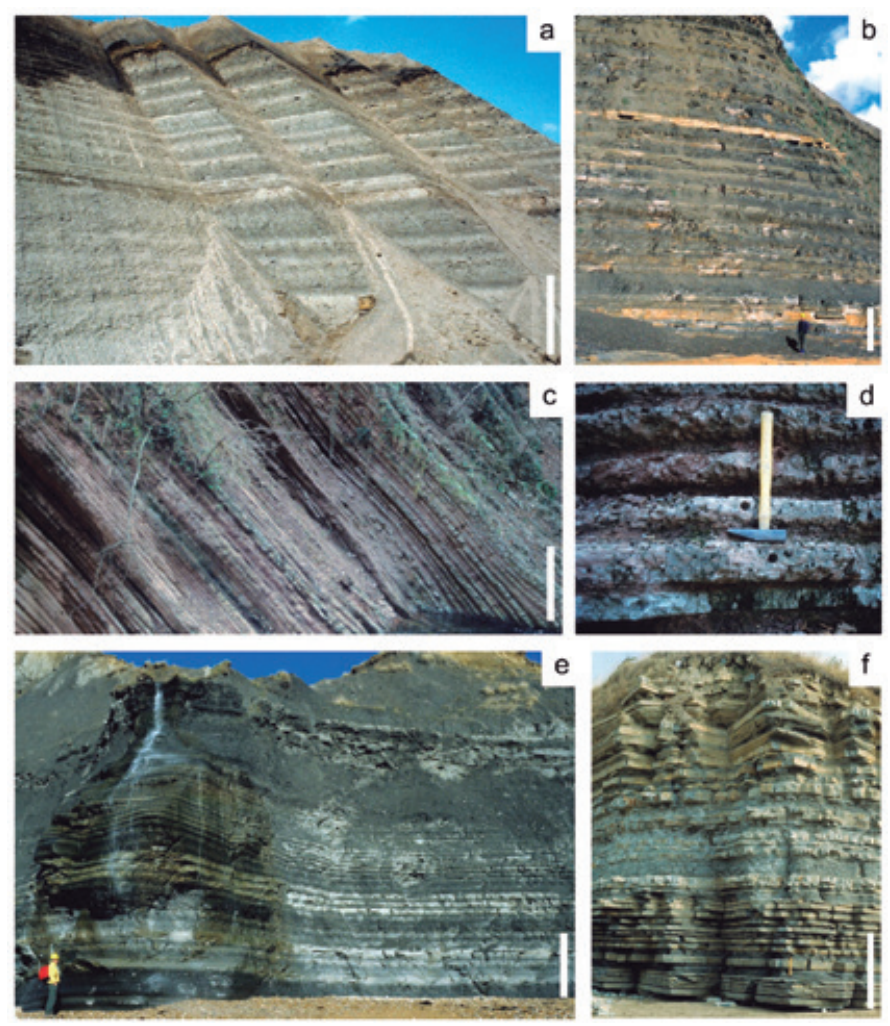

Figure 3. Field photographs of some of the formations yielding cyclostratigraphic time series. In each photograph the vertical, white scale bars indicate $2 \mathrm{~m}$. a) The Lower Oligocene Boom Clay Formation, Terhagen pit, Belgium. b) The Upper Jurassic Kimmeridge Clay Formation at Hobarrow Bay, Dorset, UK. The yellow dolostone in the cliff is the Washing Ledge Stone band with Dr Stephen Hesselbo standing on the Flats Stone Band. c) Beds 1 to 5 of Bernoulli (1964) in the Rosso Ammonitico Lombardo in Breggia Gorge, Switzerland. d) Part of bed 1 in the Rosso Ammonitico Lombardo (the hammer is $0.39 \mathrm{~m}$ long). e) The Lower Jurassic Belemnite Marls just east of Charmouth, Dorset, UK. The upper two thirds of the Belemnite Marls is visible with the top defined by a thin limestone causing the small waterfall above Dr Paul Cole. f) The Lower Jurassic Blue Lias Formation at the west end of St Mary's Well Bay, Lavernock, Glamorgan, UK. The photograph shows the interval from 1.5 to $9.3 \mathrm{~m}$ of Weedon et al. (2018) (Tilmanni and Planorbis Zones).

Figura 3. Fotografías en trabajo de campo de algunas de las formaciones que proporcionan las series temporales cicloestratigráfidcas. Las barras blancas de escala indican $2 \mathrm{~m}$. de altura. a) La formación Boom Clay del Oligoceno Inferior, Terhagen, Bélgica. b) formación de Kimmeridge Clay del Jurásico Superior en Hobarrow Bay, Dorset, Reino Unido. La dolomía amarilla es la banda de Washing Ledge Stone con Stephen Hesselbo de pie sobre la banda de Flat Stone. c) Capas 1 a 5 de Bernoulli (1954) en el Rosso Ammonitico Lombardo en Breggia Gorge, Suiza. d) Parte de la capa 1 en el Rosso Ammonitico Lombardo (el martillo mido $0.39 \mathrm{~m}$ ). e) Belemnite Marls del Jurásico Inferior al este de Charmouth Dorset, Reino Unido. Los dos tercios superiores de Belemnite Marls son apreciables con la cima definida por caliza fina que causa la pequeña cascada sobre Paul Cole. f) la formación Blue Lias del Jurásico Inferior al extremo oeste de St Mary's Well Bay, Lavernock, Glamorgan, Reino Unido. La fotografía muestra el intervalo desde 1.5 hasta $9.3 \mathrm{~m}$ de Weedon et al. (2018) (zonas Tilmanni y Planorbis).

\section{A) Lower Pleistocene, North Atlantic and Eastern Equatorial Pacific}

Before examining ancient examples, it is worth revisiting some classic examples of Pleistocene time series from the North Atlantic and East Pacific (Fig. 2). Ruddiman et al. (1986; 1987a) obtained benthic-foraminifera oxygen-isotope data $\left(\delta^{18} \mathrm{O}_{\mathrm{BF}}\right)$ from deep sea drilling project site 607 (DSDP607) at 3,427 $\mathrm{m}$ water depth on the North Atlantic Ridge (Ruddiman et al., 1987a; 1987b). The data from the 49.08 to $111.00 \mathrm{~m}$ interval corresponds to 1.211 to $2.5975 \mathrm{Ma}$ according to the time scale of Shackleton et al. (1990). Although the data were obtained at varying spacing the Lomb-Scargle Transform used for generating the power spectra allows analysis without data interpolation (see Methods section A). The power spectrum for DSDP607 in Fig. 4 contains one significant peak that exceeds the $0.01 \%$ FDR (i.e. less than 1 in 10,000 chance of a false positive) corresponding to regular cycles in depth with a wavelength of $1.82 \mathrm{~m}$. The Bayesian probability of the pre-whitened detrended data is 1.00 at the same scale. The total thickness analysed, divided by the wavelength of the cycles, indicates 34 cycles. Given the time range (derived from orbital tuning by Shackleton et al., 1990) the isotopic cycles in the depth domain correspond to an average period of $40.77 \mathrm{kyr}$ or, as expected, very close to the period of the obliquity cycle in the Pleistocene.

Shackleton et al. (1990) studied oxygen isotope ratios in benthic foraminifera $\left(\delta^{18} \mathrm{O}_{\mathrm{BF}}\right)$ from Ocean Drilling Program site 677 (ODP677) at 3,461 m water depth in the eastern equatorial Pacific (Becker et al., 1987). They demonstrated that direct orbital tuning of the inferred regular cycles to the orbital history resulted in more linear age/depth plots for ODP677 and DSDP607 than tuning that was constrained by the, then accepted, $\mathrm{K}-\mathrm{Ar}$ radiometric age for the Brunhes/Matuyama palaeomagnetic reversal. Their data from 47.95 to 111.80 $\mathrm{m}$ corresponds to 1.210 to $2.600 \mathrm{Ma}$ on their time scale (i.e. almost exactly the same time interval as the data obtained for DSDP607). Visually there is great similarity between the DSDP607 and ODP677 $\delta^{18} \mathrm{O}_{\mathrm{BF}}$ data (Fig. 4). The latter dataset has more closely-spaced samples, albeit with gaps, so the corresponding power spectrum, again generated without data interpolation, has a far higher Nyquist frequency than that of the DSDP607 data. There are two spectral peaks exceeding the $5 \%$ FDR corresponding to cycles with wavelengths of 2.28 and $1.88 \mathrm{~m}$. The Bayesian probability is 1.00 at the scale of the $1.88 \mathrm{~m}$ cycles. $\delta^{18} \mathrm{O}_{\mathrm{BF}}$ is a bottom water proxy, and since ocean bottom waters are well-mixed, it provides a global isotope signal. Therefore, the cluster of spectral peaks centred on 2.28 and $1.88 \mathrm{~m}$ simply 


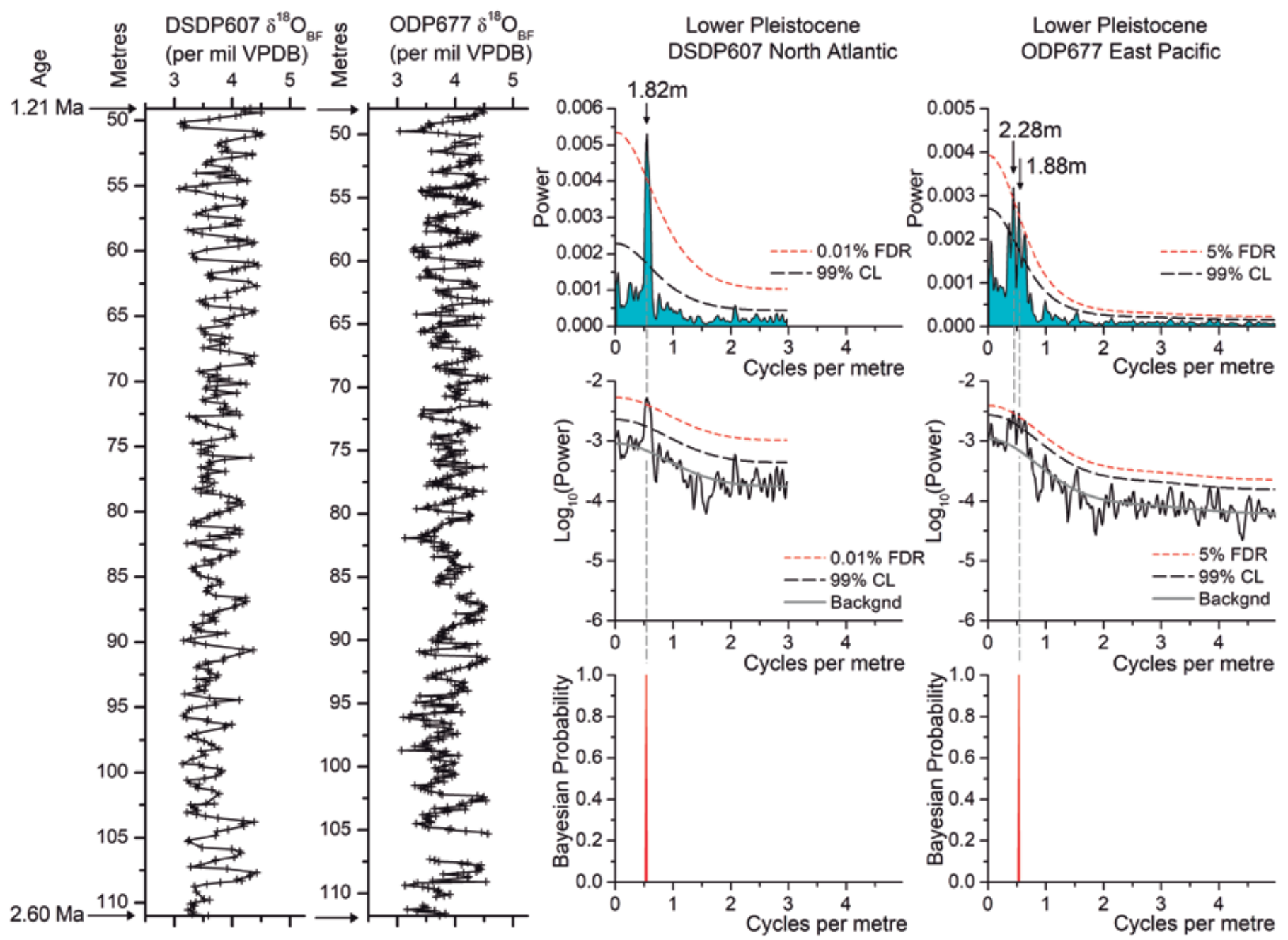

Figure 4. Time series, and corresponding power spectra, of Lower Pleistocene oxygen isotopes from benthic foraminifera from DSDP site 607 (North Atlantic) and ODP site 677 (eastern Equatorial Pacific, Fig. 2). See Fig. 1 for abbreviations.

Figura 4. Series temporales, y sus espectros de potencia correspondientes, de los isótopos de oxígeno del Pleistoceno Inferior de foraminíferos bentónicos de la localización DSDP 607 (Atlántico Norte) y ODP 677 (Pacífico ecuatorial del Este, Fig. 2). Ver Figura 1 para las abreviaturas.

relate to obliquity cycles recorded as of variable wavelength due to unsteady accumulation rates (cf. Huybers and Wunsch, 2004).

\section{B) Lower Oligocene, Western Equatorial Atlantic}

Four of the ODP Leg 154 sites on the Ceara Rise near the mouth of the Amazon river in the western equatorial Atlantic (Fig. 2) penetrated Oligocene strata (Curry et al., 1995). At all sites there are clear bedding cycles caused by variations in calcium carbonate contents which are inversely related to magnetic susceptibility (MS). At ODP site 925 at $3041 \mathrm{~m}$ water depth, due to the induration of the sediments rotary coring was used in the older interval so the shipboard magnetic susceptibility loop sensor was often applied to core that did not fill the core liner. Consequently, Weedon (1997) re-measured the volume MS directly on the split cores with a Bartington F-probe. ODP site 929 at $4356 \mathrm{~m}$ water depth has microfossils that are sometimes poorly preserved due to partial carbonate dissolution on the sea floor.

Power spectra based on the new magnetic susceptibility measurements from four Oligocene intervals at ODP site 925 and an additional 12 intervals of colour reflectance data for sites 926, 928 and 929 were illustrated by Weedon et al. (1997). The spectra had backgrounds obtained from quadratic fits; in 9 cases the $99 \%$ confidence interval was exceeded. Weedon et al. (1997) used the inference that the main cyclicity is due to obliquity 


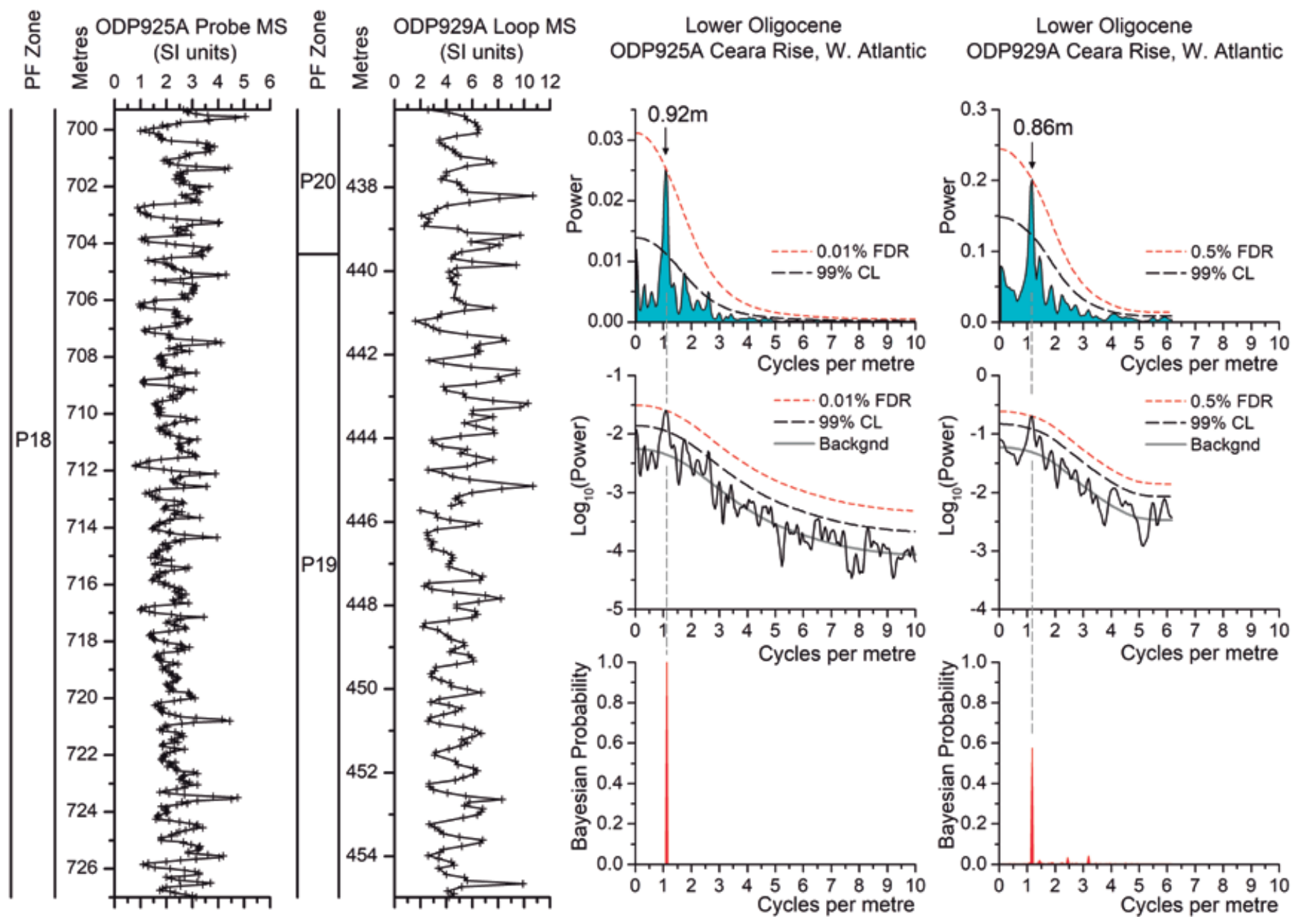

Figure 5. Time series, and corresponding power spectra, of Lower Oligocene magnetic susceptibility (MS) measured on cores from ODP hole 925A and ODP hole 929A (Ceara Rise, western Equatorial Atlantic, Fig. 2). PF Zone = Planktonic foraminifera Zone.

Figura 5. Series temporales, y sus espectros de potencia correspondientes, de susceptibilidad magnética (MS) del Oligoceno Inferior en núcleos del agujero ODP 925A y ODP 929A (Ceara Rise, Atlántico ecuatorial del Oeste). PF Zone = Zona planctónica de foraminíferos.

(40 kyr), to provide the first "floating" astrochronological estimate for the duration of the Oligocene. Shackleton et al. (1999) orbitally tuned the Miocene and Oligocene MS and gamma ray data. ODP Leg 154 sediment composition and isotopic data were later used to refine the orbital tuning of the Oligocene (Zachos et al., 1997; Zachos et al., 2001; Palike et al., 2003).

The post-cruise MS data (Weedon, 1997) are shown for hole 925A cores 45R to 47R in Fig. 5. The power spectrum has a well-defined spectral peak just reaching the $0.01 \%$ FDR associated with a cycle wavelength of $0.92 \mathrm{~m}$ supported by the Bayesian probability of 1.00 . Shipboard loop sensor MS data from hole 929A cores 47X and 48X are shown in Fig. 5. The power spectrum indicates regular cyclicity with a wavelength of $0.86 \mathrm{~m}$ with the spectral peak exceeding the $0.5 \%$ FDR. The Bayesian probability at the corresponding frequency is 0.576 .

\section{C) Lower Oligocene, Belgium}

The Boom Clay Formation, part of the type Rupelian (Lower Oligocene), deposited in a shallow part of the southern North Sea, is exposed in Belgium within a series of clay pits (Fig. 2, Vandenberghe, 1978). Metre-scale bedding is related to variations in the siltto-clay ratio, calcium carbonate and organic carbon contents (Fig. 3a). Van Echelpoel and Weedon (1990) analysed a grain size record from Terhagen pit with a Fourier power spectrum and indicated regular cycles 

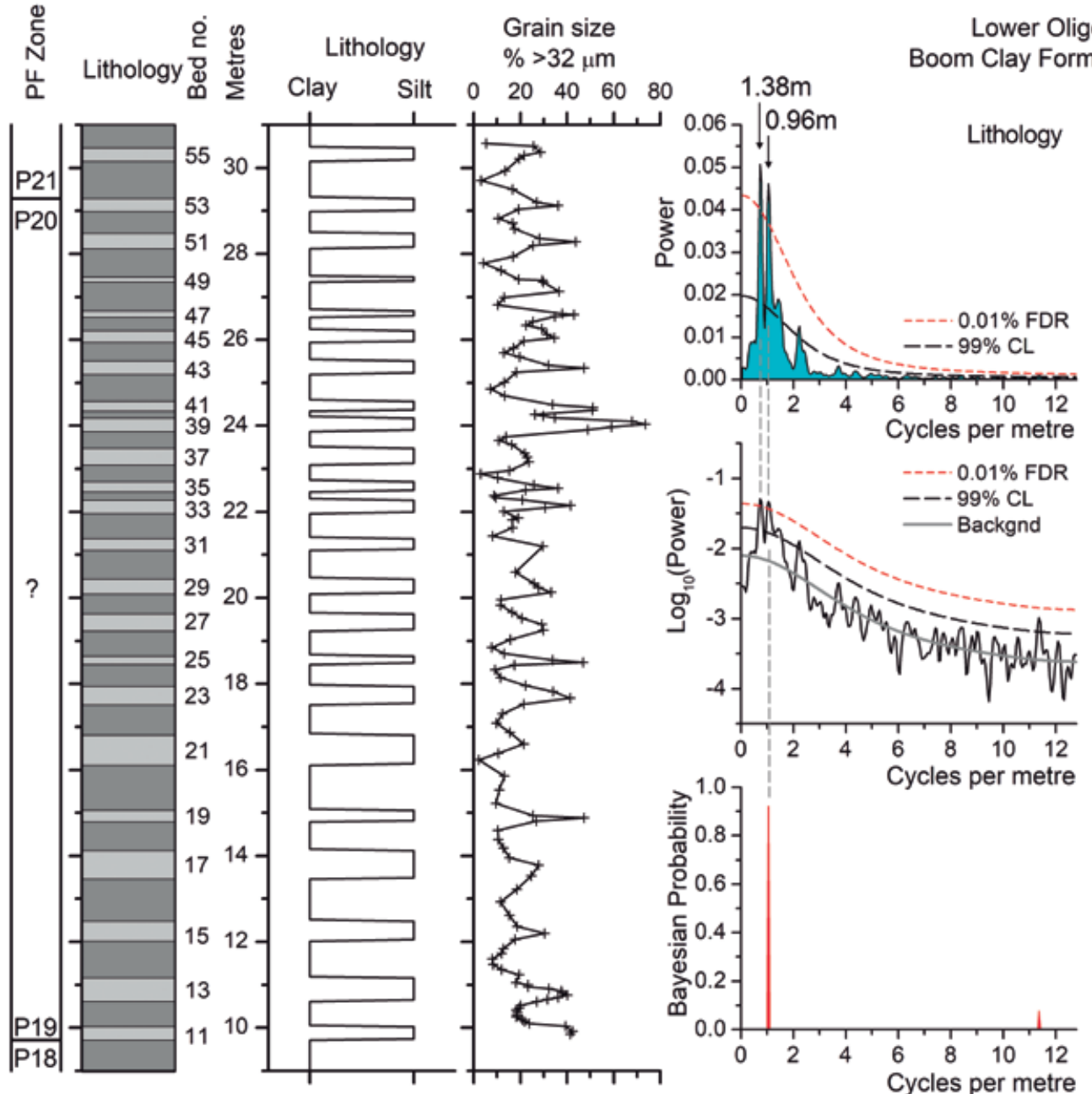

Lower Oligocene, Palaeogene

Boom Clay Formation, Terhagen, Belgium
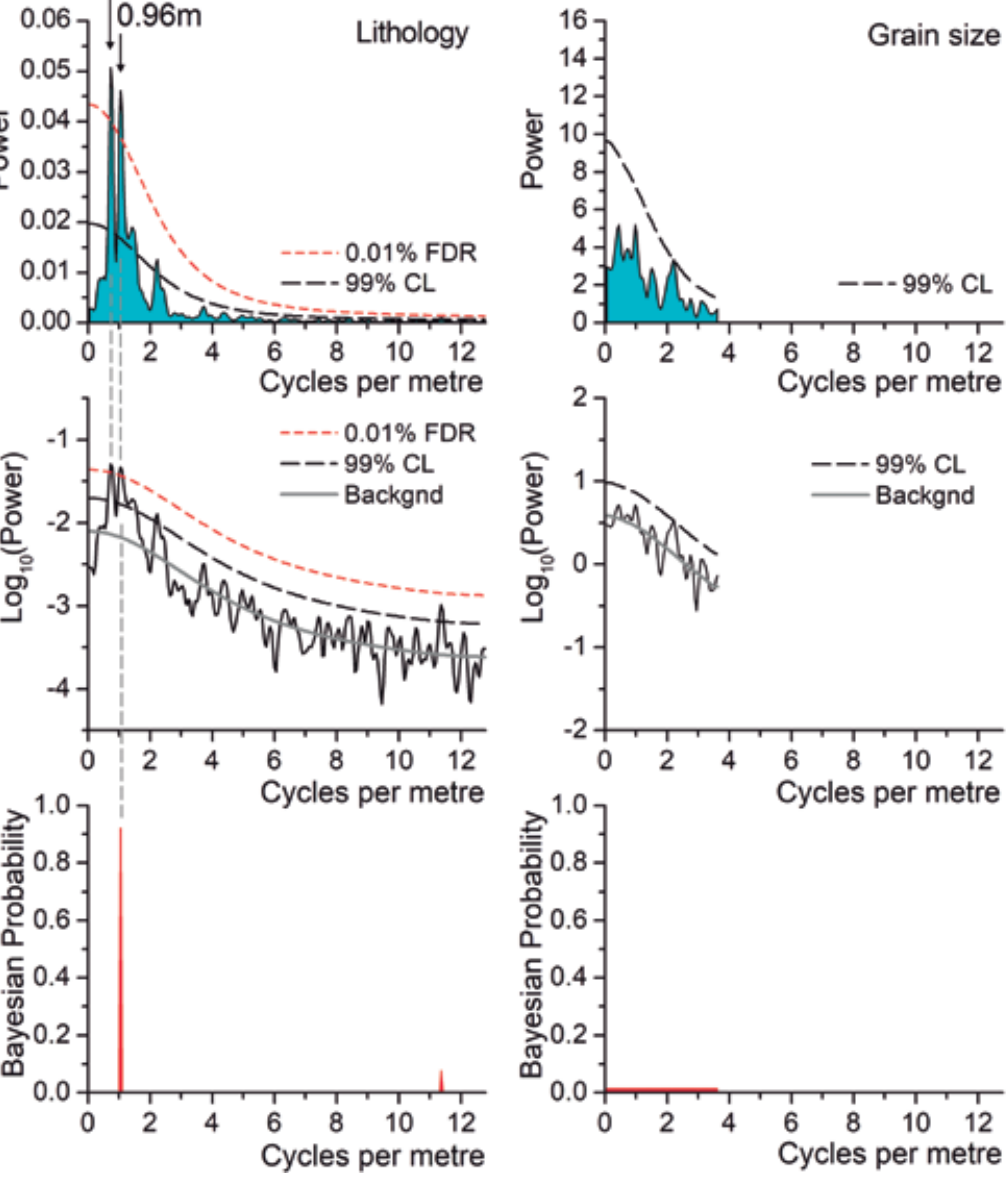

Figure 6. Digitized lithological log data and grain size analysis data, and corresponding power spectra, from the Lower Oligocene Boom Clay Formation (Terhagen, Belgium, Figs 2 and 3a). Bed numbers follow Vandenberghe (1978).

Figura 6. Datos litológicos digitalizados y datos de análisis de tamaño de grano, y sus espectros de potencia correspondientes, de la formación Boom Clay del Oligoceno Inferior (Terhagen, Bélgica, Figs. 2 y 3a). Los números de capa se dan acorde con Vandenberghe (1978).

with a wavelength of $1.0 \mathrm{~m}$ and $0.46 \mathrm{~m}$ significant at the $80 \%$ level (i.e. at a confidence level now considered too low to be significant). Additionally, a digitized lithological log composited from several pits, but mainly obtained from Terhagen, was analysed with a Walsh power spectrum, without confidence intervals, yielding a spectral peak corresponding to a wavelength of $1.38 \mathrm{~m}$. The cycles in mean grain size were believed to relate to changing bottom-water turbulence related to storm intensity and/or glacio-eustatic sea level linked to short eccentricity and obliquity cycles. Downhole logs from the Dessel 1 borehole in Belgium, covering a longer interval than that analysed by Van Echelpoel and Weedon (1990), led to broadly similar conclusions with an additional claim of 405 kyr eccentricity glacio-eustatic forcing of sedimentation (Abels et al., 2007). The Boom Clay represents a portion of the more widespread Rupel Clay Member currently being investigated in the sub-surface in the Netherlands (Vis, et al., 2016).

The data in Fig. 6 cover the central part of the Boom Clay Formation as analysed by Van Echelpoel and Weedon (1990). Although the positions of planktonic foraminiferal zones have been indicated in the figure, the biostratigraphy remains problematic (Abels et al., 2007). The power spectrum of the digitized lithological log indicates two peaks exceeding the $0.01 \%$ FDR level and corresponding to 1.38 and $0.96 \mathrm{~m}$ cycles. There is strong independent support for the $0.96 \mathrm{~m}$ cycle (Bayesian probability $=0.922$ ). On the other hand, there is no evidence for regular cycles within the grain size data (no spectral peak exceeding $5 \%$ FDR and the maximum Bayesian probability across all frequencies is 0.014). Visually there appears 


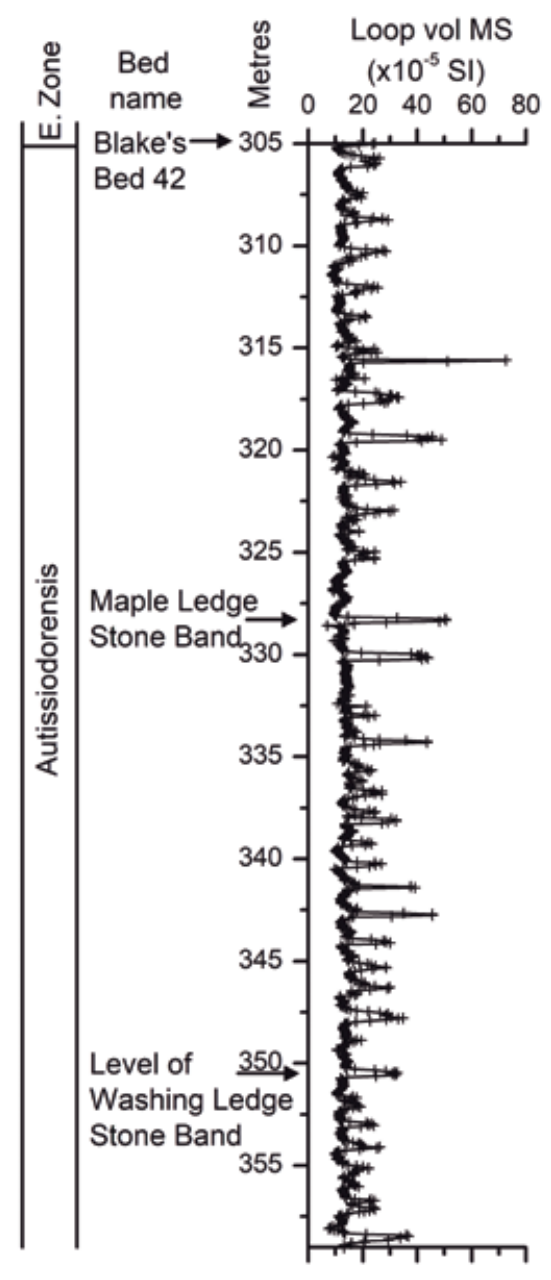

Photoelectric factor (Barns/electron)
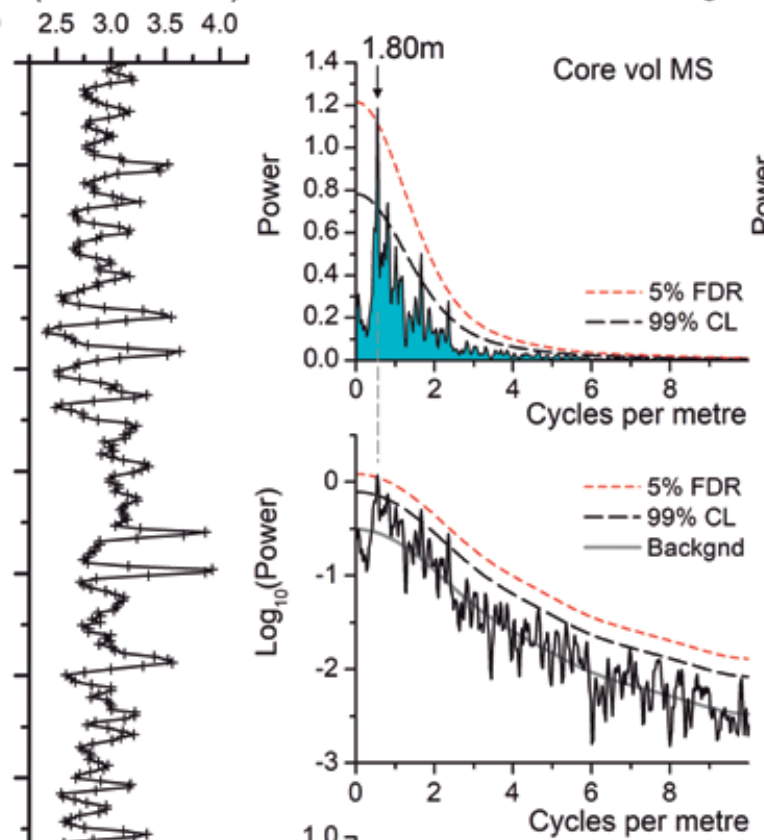

Kimeridgian, Jurassic

Kimmeridge Clay Formation, Dorset, UK
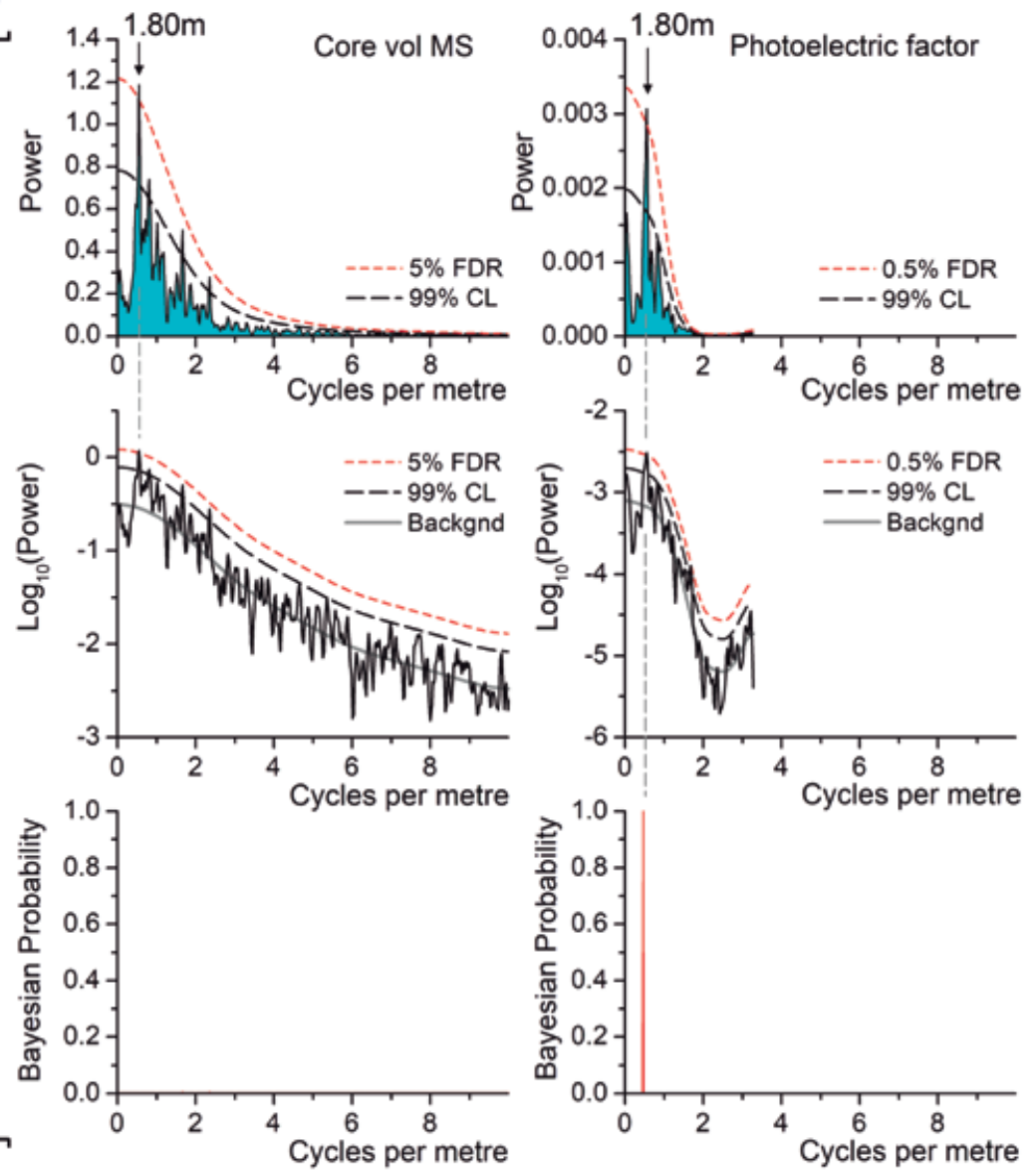

Figure 7. Magnetic susceptibility of core and downhole Photoelectric factor (PEF) on the common depth scale with corresponding power spectra from the Upper Jurassic Kimmeridge Clay Formation (Dorset, UK, Figs 2 and $3 b$ ).

Figura 7. Susceptibilidad magnética del núcleo y factor fotoeléctrico (PEF) de fondo de pozo en escala de profundidad común con el espectro de potencia correspondiente de la formación Kimmeridge Clay del Jurásico Superior (Dorset, Reino Unido, Figs. 2 y 3).

to be a long-term decrease and increase in the spacing of the beds with minimum spacing near the 22 to $25 \mathrm{~m}$ interval. This probably means that the pair of significant regular cycles detected in the digitized lithological log result from a long-term variation in accumulation rates. Following Abels et al. (2007) this cyclicity is most likely to be due to the obliquity cycle - as found in the essentially coeval Early Oligocene Ceara Rise examples discussed previously.

\section{D) Kimmeridgian Stage, Jurassic, UK}

The Kimmeridge Clay Formation from the Upper Jurassic provides the principal source rock for North Sea oil and was deposited on a continental shelf (Barnard and Cooper, 1981). The Rapid Global Geological Events (RGGE) Anatomy of a Source Rock project involved field logging and measurement of volume magnetic susceptibility using a Bartington F-probe through the type section of the Kimmeridge Clay Formation in Dorset, UK (Figs 2 and 3b, Weedon et al., 1999). Additionally, boreholes with continuous coring and downhole logging at Metherhills and Swanworth Quarry were used to characterise the whole formation (Gallois, 2000; Morgans-Bell et al., 2001). Combined with loop-sensor measurements of MS on the whole cores, field MS data contributed to the generation of a "common depth scale" to allow integration of the field, core and downhole data (Weedon et al., 1999; Morgans-Bell et al., 2001).

Weedon et al. (1999) argued that at the metre scale there are two scales of regular cyclicity inferred to relate to the obliquity and precession cycles. Weedon et al. (2004) created a "stacked" or averaged time se- 
ries using data on the common depth scale based on standardized time series of i) loop measurements of magnetic susceptibility, ii) downhole measurements of the photoelectric factor (PEF) and iii) downhole total gamma ray counts. Spectral analysis of the stacked signal indicated two scales of cyclicity ("long" and "short" cycles). In the power spectra shown (figure 5 of Weedon et al., 2004) in many cases the spectral peaks easily exceed the $99 \%$ confidence level. However, the stacked signal data had been pre-processed to remove very low frequency variations so that the spectral backgrounds should have been adjusted at the lowest frequencies (Vaughan et al., 2015).

Huang et al. (2010) used the relatively widely spaced measurements of total organic carbon (average spacing $0.2 \mathrm{~m}$, range 0.01 to $0.72 \mathrm{~m}$ on the common depth scale) together with very high-resolution downhole formation microscanner data (spacing $0.0127 \mathrm{~m}$ ) to assess cyclicity at the tens to hundreds of metre scales. They identified regular cyclicity and linked the approximately $40 \mathrm{~m}$ cyclicity to the $405 \mathrm{kyr}$ eccentricity cycle and experimented with tuning different scales of cyclicity in the depth domain to different target orbital cycles. Despite the different approaches used ("bottom up" by Weedon et al., 2004, "top-down" by Huang et al., 2010) the overall astrochronological estimates for the duration of the ammonite zones involved are remarkably similar.

Vaughan et al. (2011) examined the whole of the PEF log on the common depth scale and concluded there is no evidence for regular cyclicity. This contrasting interpretation compared to previous studies is undoubtedly partly linked to their valid use of corrections of the confidence level (FAL) for multiple testing. On the other hand, they acknowledged that variations in accumulation rate had been documented previously, but appear not to allow for the fact that "spectral smearing" due to varying accumulation rates has the effect of decreasing the likelihood of detecting regular cycles (Weedon, 2003; Huybers and Wunsch, 2004; Kemp, 2016; Martinez et al., 2016). Since they did not examine stationary subsections of data their testing does not rule out the presence of regular cyclicity.

Fig. 7 shows magnetic susceptibility measured on whole cores using a loop sensor and downhole photoelectric factor data from 305.0 to $359.0 \mathrm{~m}$ on the common depth scale from the Swanworth Quarry 1 borehole. Much of this interval is illustrated in photograph Fig. $3 b$ where clear metre-scale alternations of mudstones and shales are visible as well as the yellow-weathering dolostone Washing Ledge Stone Band (this stone band is absent in the Swanworth Quarry 1 borehole).
The core MS data produce a spectral peak that exceeds the $5 \%$ FDR, and corresponds to $1.80 \mathrm{~m}$ cycles, but there is no related large Bayesian probability. The PEF data produce a spectral peak at the same frequency as the susceptibility data which exceeds the $0.5 \%$ FDR and there is an associated Bayesian probability of 1.00. Since the susceptibility spectral peak passes a lower FDR level than that for PEF a lower degree of regularity is implied. This lower degree of regularity is reflected in the lack of high Bayesian probability for the MS record. These results are related to random centimetre-scale distortions of the thickness of the core material due to numerous bedding-parallel cracks in the mudrocks and shale due to pressure release on core extraction. Such small-scale distortions of the core thicknesses could not be removed during creation of the common depth scale. The steep slope of the main PEF spectrum and the upturn in background power at the highest frequencies apparently results from the smoothing imposed by post-processing of the PEF downhole data. The $1.80 \mathrm{~m}$ cycles detected here can be related to the "Iong cycles" of Weedon et al. (2004) isolated by band-pass filtering in their figure 4.

\section{E) Pliensbachian and Toarcian Stages, Jurassic, Swit- zerland}

The mid Jurassic Toarcian Stage Rosso Ammonitico Lombardo (Fig. 3c and d) and the Pliensbachian Stage Morbio Formation are exposed at Breggia Gorge in the Southern Alps of Switzerland (Fig. 2, Bernoulli, 1964; Wiedenmayer, 1980). These units were deposited in the Lombardy Basin that was formed by progressive Late Triassic to mid Jurassic rifting on part of a drowned passive margin (Winter and Bosellini 1981; Berra et al. 2009). Unlike the other terrestrially-exposed strata described in this paper deposition was in deep water (bathyal) though with rare dropstones probably transported by drift wood (Bernoulli and Ulmer 2016). The Rosso Ammonitico Lombardo consists of centimetre-scale grey or red limestones alternating with centimetre-scale red or purple shale often with clear burrow mottling between lithologies (Fig. 3c and d). The Lower Morbio Formation has white decimetre-scale limestone beds with cherts alternating with green marl or shale.

The digitized lithological logs of Weedon (1987, data listed in Appendix 6) from the Rosso Ammonitico and the Lower and Upper Morbio Formation were analysed using Walsh power spectra. Since the Walsh transform used was restricted to analysis of a power of two number of data points, the data were analysed 


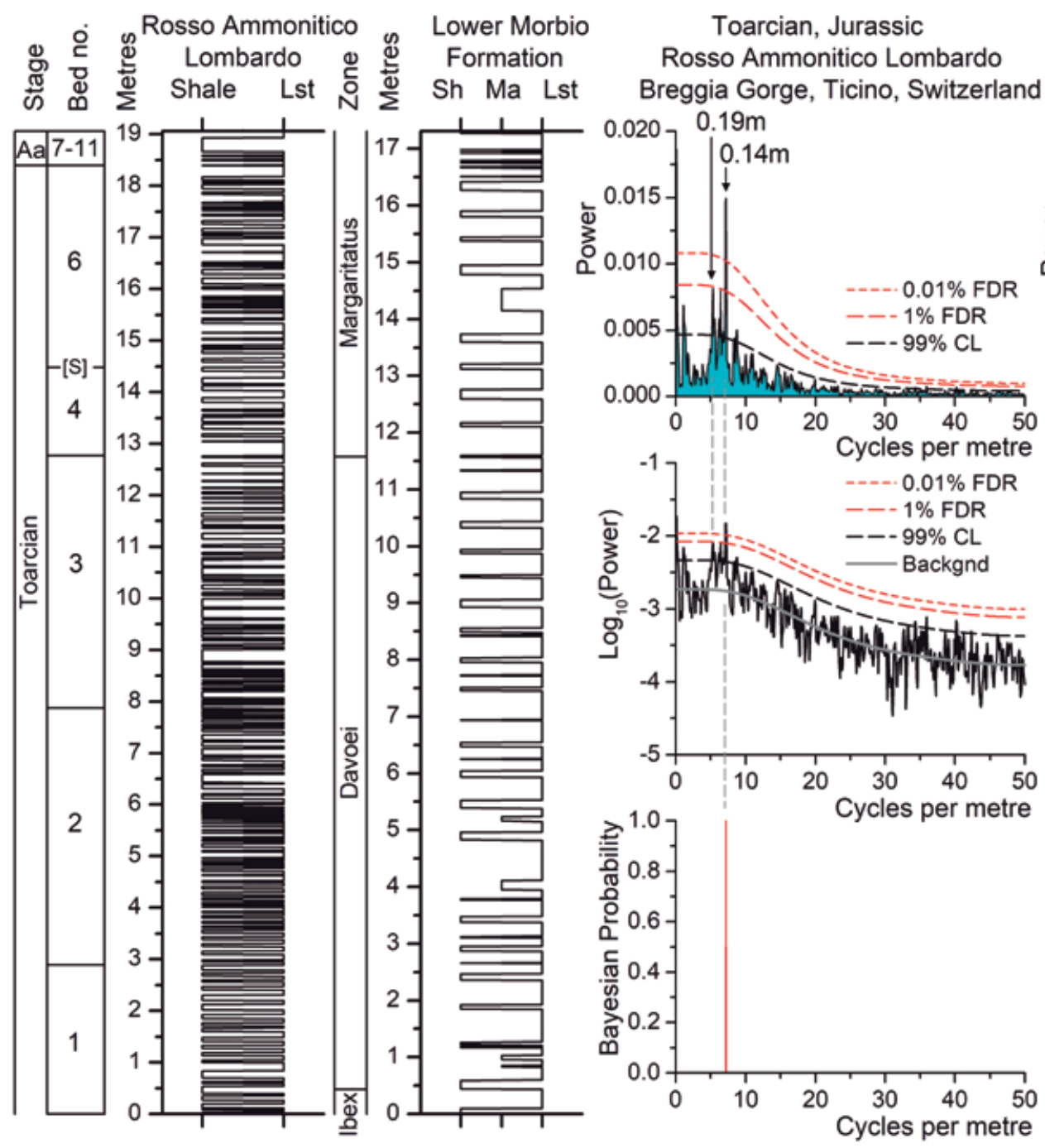

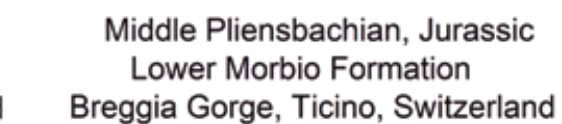

$0.51 \mathrm{~m}$
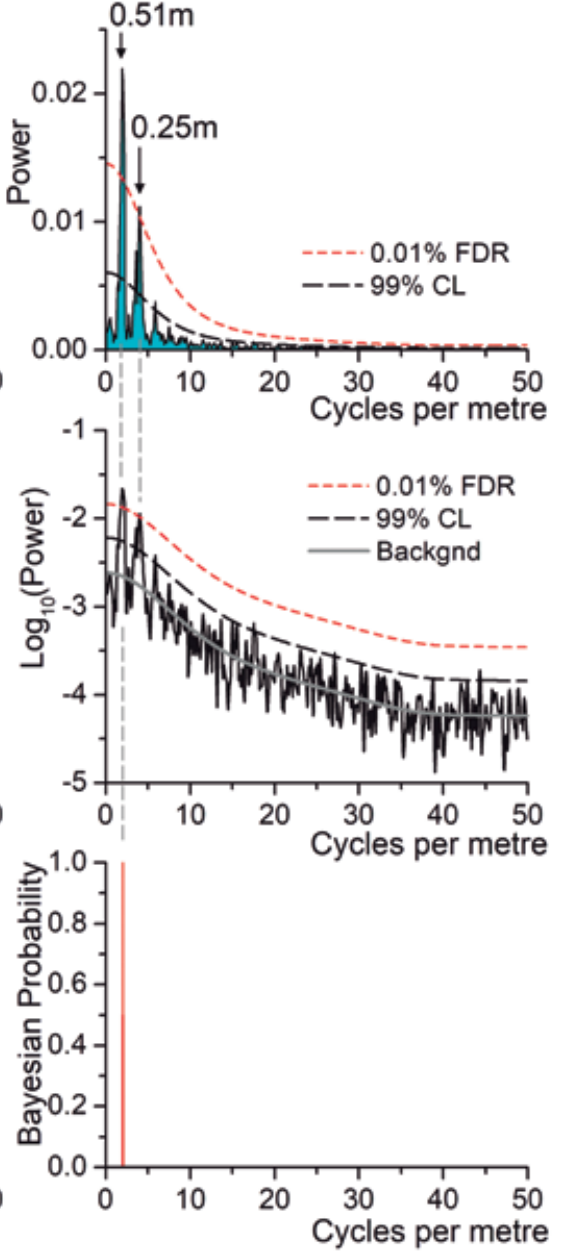

Figure 8. Digitized lithological logs, and corresponding power spectra, for the Rosso Ammonitico Lombardo (Toarcian Stage, Fig. 3c and d) and the Lower Morbio Formation (mid Pliensbachian Stage), Lower Jurassic (Breggia Gorge Switzerland, Fig. 2). Bed numbers follow Bernoulli (1964). Lst = Limestone, Ma = Marl, Sh = Shale, Aa = Áalenian, (S) = Slump (excluded).

Figura 8. Datos litológicos digitalizados, y sus espectros de potencia correspondientes, de Rosso Ammonitico Lombardo (Toarciano, Fig. $3 d y d)$ y de la formación Morbio Inferior (Pliensbachiano medio), Jurásico Inferior (Breggia Gorge, Suiza, Fig. 2). Los números de capa se dan acorde con Bernoulli (1964). Lst = Caliza, Ma = Marga, Sh = Esquisto, Aa = Aaleniano, (S) = Slump (excludio).

in subsections. The results, for the longest subsections only, were described by Weedon (1989). Since here a Lomb-Scargle algorithm has been used for processing (suitable for any number of data points), and there are no obvious non-stationary features in the time series, the whole of the digitized logs from the Rosso Ammonitico Lombardo (excluding slump bed 5 of Bernoulli, 1964) and from the Lower Morbio Formation have been analysed.

The power spectrum of the Rosso Ammonitico Lombardo data shows a main spectral peak associated with oscillations of wavelength $0.14 \mathrm{~m}$ that exceeds the $0.01 \%$ FDR with high Bayesian probabili- ty (1.00). Nearby is another peak exceeding the $1 \%$ FDR indicating oscillations of $0.19 \mathrm{~m}$. The closeness of these wavelengths (wavelength ratio 1.36) is interpreted here to indicate a record of a single orbital cycle encoded with variations in accumulation rates. Weedon (1989) suggested that the main cyclicity is related to orbital precession on the basis that a peak corresponding to $0.85 \mathrm{~m}$ cycles, recorded here as a peak only exceeding the standard $99 \%$ confidence level and a wavelength of $0.91 \mathrm{~m}$, results from forcing by the short eccentricity cycle.

The power spectrum of the Lower Morbio Formation has two peaks exceeding the $0.01 \%$ FDR corre- 


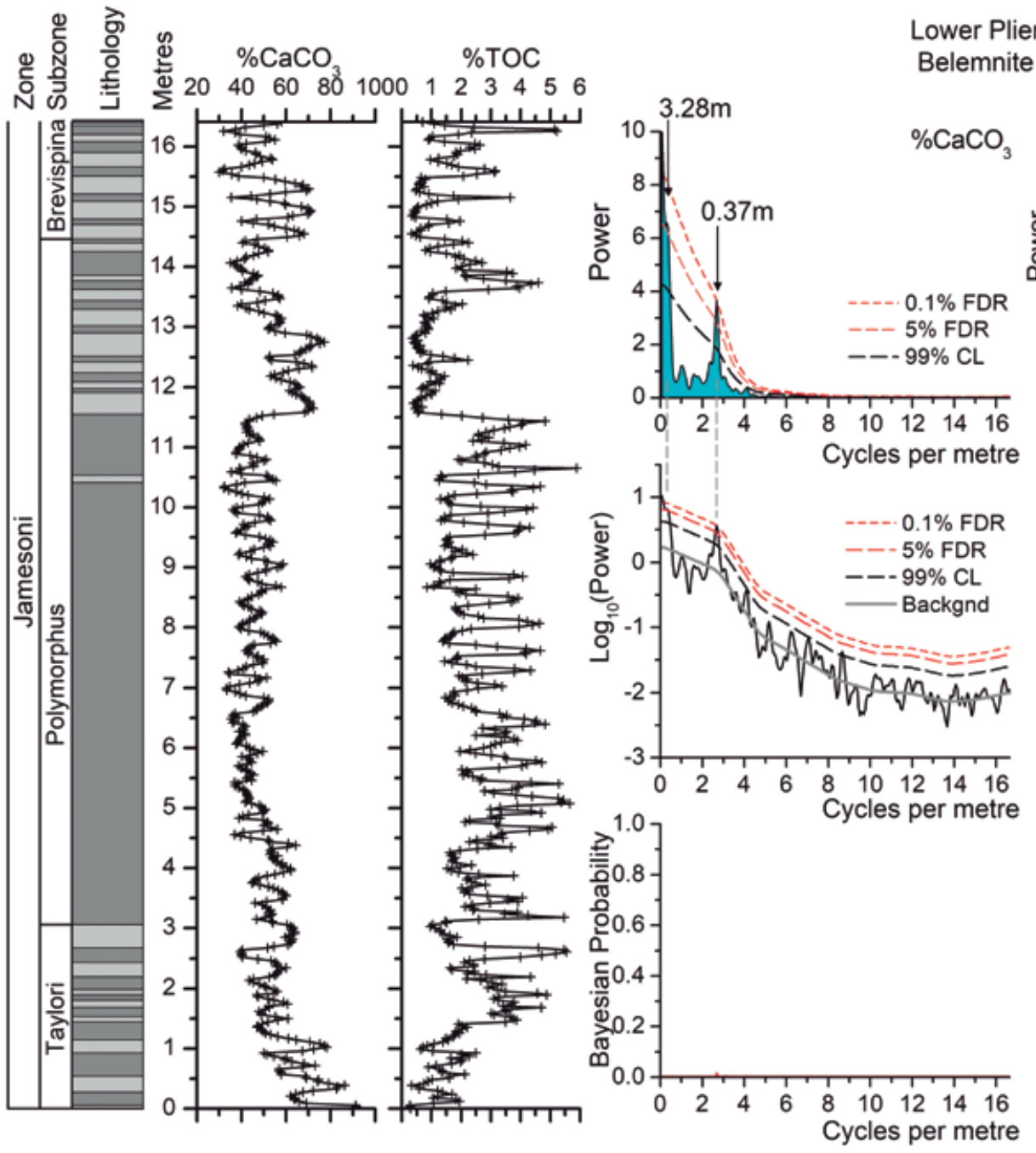

Lower Pliensbachian, Jurassic Belemnite Marls, Dorset, UK
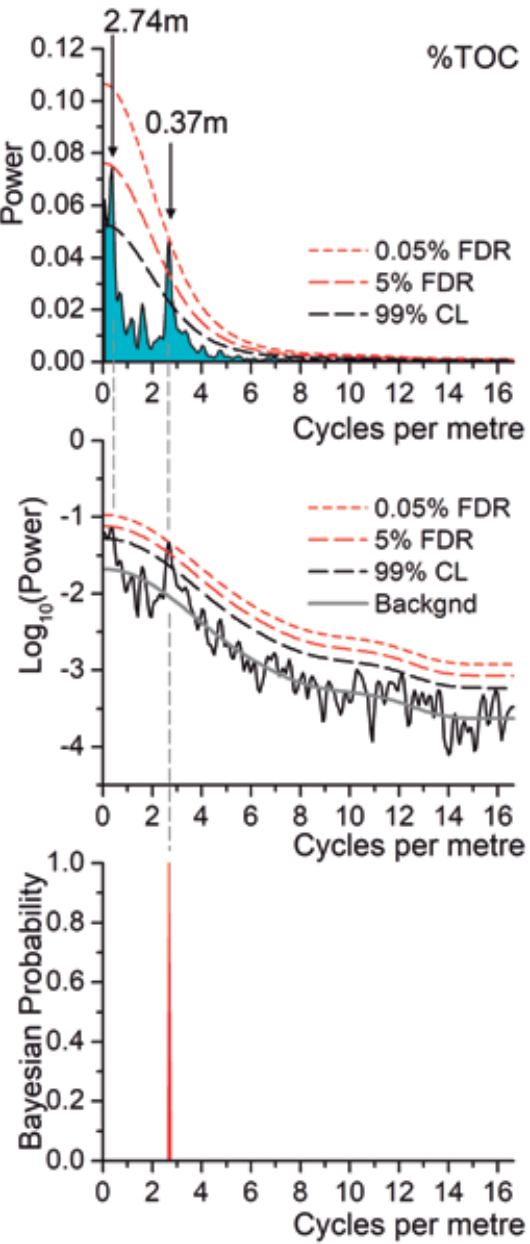

Figure 9. Time series of $\% \mathrm{CaCO}_{3}$ and \%TOC, and corresponding power spectra, from the lower two thirds of the Lower Jurassic (Lower Pliensbachian Stage) Belemnite Marls (near Charmouth, Dorset, UK, Figs 2 and 3e).

Figura 9. Series temporales de \% de $\mathrm{CaCO}_{3}$ y \% de TOC, y sus correspondientes espectros de potencia, de los dos tercios inferiores de Belemnite Marls del Jurásico Inferior (Pliensbachiano Inferior) (cerca de Charmouth, Dorset, Reino Unido, Figs. 2 y 3e).

sponding to cycles of 0.51 and $0.25 \mathrm{~m}$. The longer wavelength cycles are associated with high Bayesian probability (1.00). The asymmetry in the lithological log (thick limestones alternating with, usually, much thinner shale and marl beds) has generated a spectral harmonic of the main cyclicity at very close to half the wavelength (i.e. $0.51 \mathrm{~m} / 0.25 \mathrm{~m}=2.04$ ). As for the Rosso Ammonitico Lombardo data, the main cyclicity was interpreted by Weedon (1989) to record precessional forcing.

All the data collected by Weedon (1987) from the upper Pliensbachian Upper Morbio Formation have also been analysed, but are not illustrated here. The corresponding power spectrum has a peak exceeding the $0.01 \%$ FDR related to cycles of $0.12 \mathrm{~m}$ - close to the wavelength of $0.13 \mathrm{~m}$ reported by Weedon (1989) for a subsection of these data.

\section{F) Pliensbachian Stage, Jurassic, UK}

The hemipelagic Lower Pliensbachian Belemnite MarIs (also known as the Stonebarrow Member of the Charmouth Mudstone Formation of Page, 2010) is exposed near Charmouth on the south coast of Dorset, UK (Figs 2). Alternating decimetre-scale light- and dark-grey marls, with burrow mottling between lithologies, form beds that can be traced laterally in the cliffs for kilometres between Charmouth and Seatown (Fig. 3e). Weedon and Jenkyns (1999) measured calcium carbonate contents $\left(\% \mathrm{CaCO}_{3}\right)$ and total organic 
Lower Pliensbachian, Jurassic

Belemnite Marls, Dorset, UK
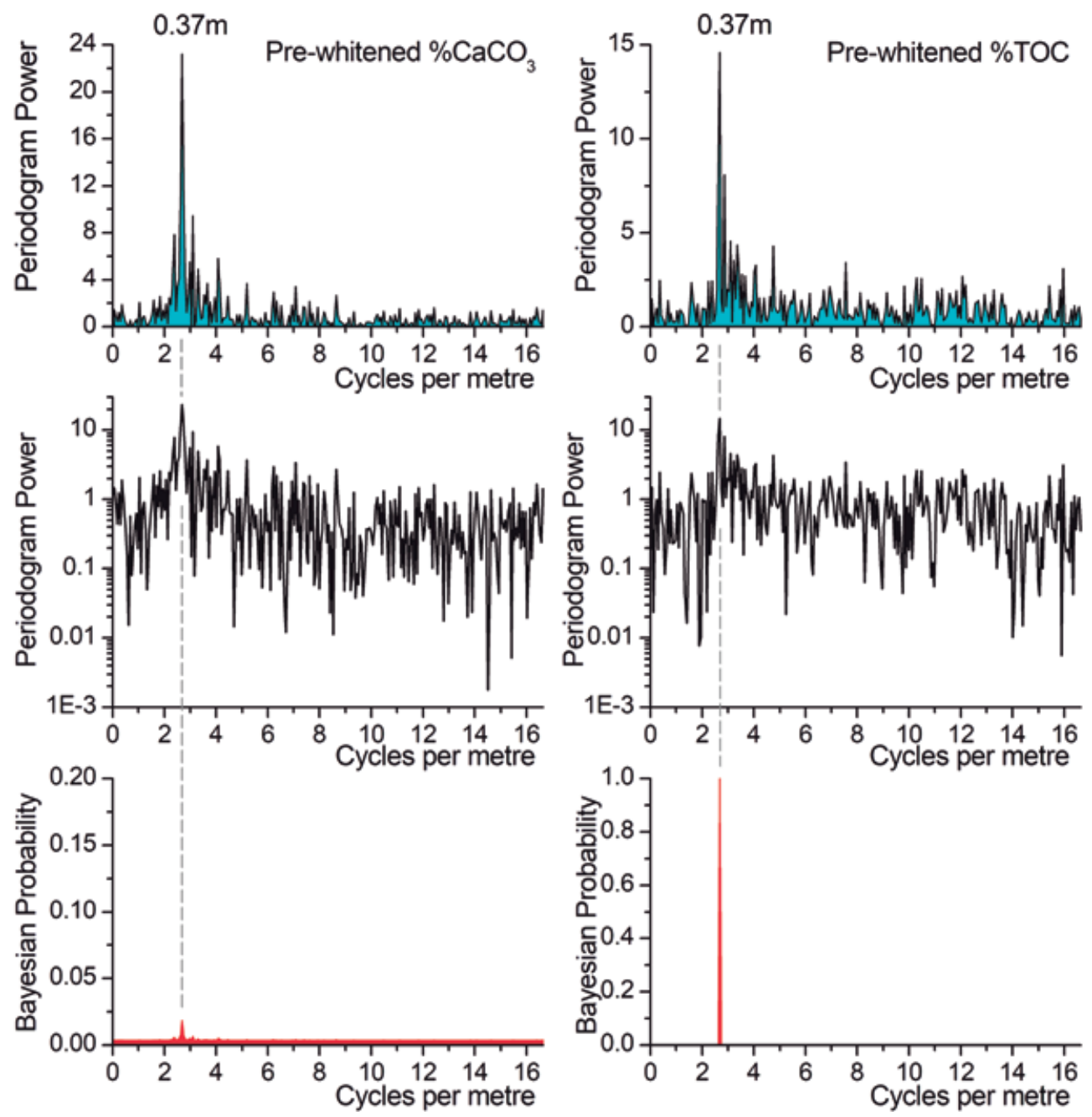

Figure 10.Top: Periodograms of the linearly detrended and pre-whitened $\% \mathrm{CaCO}_{3}$ and $\% \mathrm{TOC}$ data from the Belemnite Marls. Middle: The same periodograms with a logarithmic scale on the vertical axes. Bottom: Bayesian probability spectra of the same pre-whitened data. Note that the Bayesian probability scale for the $\% \mathrm{CaCO}_{3}$ data is limited to 0.2 instead of 1.0 as shown in Fig. 9.

Figura 10. Arriba: Periodogramas de los datos de \% de $\mathrm{CaCO}_{3}$ y $\%$ de TOC, con tendencias eliminadas linealmente y pre-blanqueados, de Belemnite Marls. Centro: Los mismos periodogramas con una escala logarítmica en el eje vertical. Abajo: Espectros de probabilidad bayesiana de los mismos datos pre-blanqueados. Nota: La escala de probabilidad bayesiana para \% de CaCO está limitada a 0.2 en lugar de 1.0 tal y como se muestra en la Fig. 9.

carbon contents (\%TOC) using samples collected at 3 $\mathrm{cm}$ intervals. This demonstrated decimetre-scale variations in composition even within thick intervals of dark marl. The decimetre-scale bedding in the lower two thirds of the Belemnite Marls is succeeded by progressively thinner beds in the upper third (Fig. 3e shows the middle and upper thirds). This upper interval of decreasing bed thickness was inferred to be due to decreasing accumulation rates related to winnowing of fines (carbonate mud and clay) which explain the observed increased concentrations of bioclasts and culminating in a thin limestone bed associated with a significant biostratigraphic gap (Weedon and Jenkyns, 1999). The erratic nature of the uppermost measurements is almost certainly the result of aliasing the topmost, thinnest beds (above the $22.2 \mathrm{~m}$ level, Weedon and Jenkyns, 1999; Weedon, 2003). Consequently, these aliased topmost data were excluded from the time series analysis.

Spectral analysis indicated regular cycles of 0.37 $\mathrm{m}$ in $\% \mathrm{CaCO}_{3}$ and $\%$ TOC for the 0.0 to $16.41 \mathrm{~m}$ interval (lower two thirds of the unit) with peaks exceeding the $99 \%$ confidence level judged against a quadratic fitting of the spectral background (Wee- 

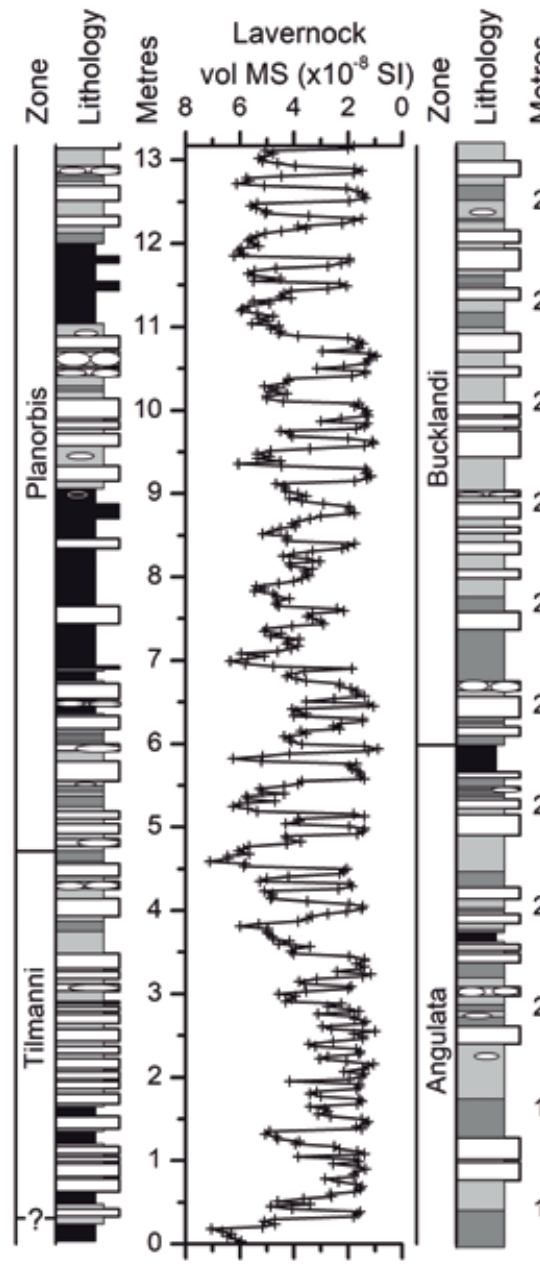
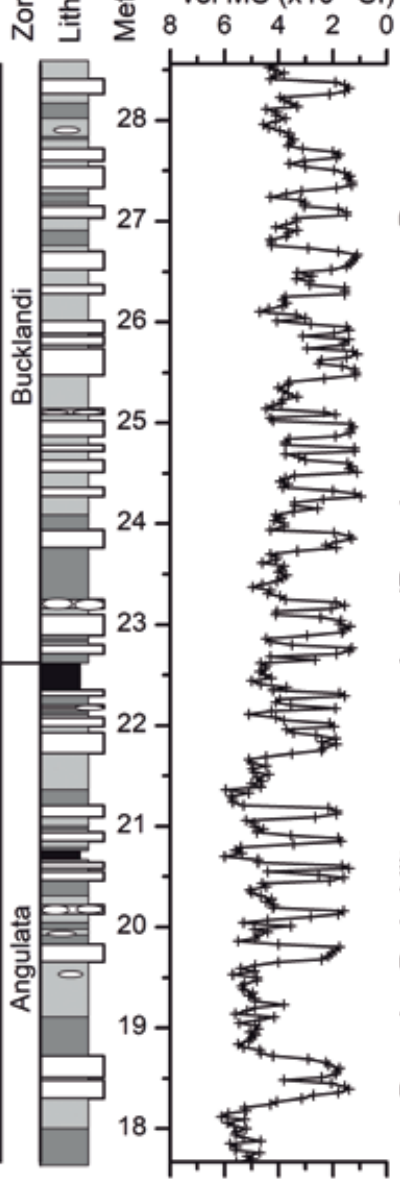

Southam Quarry vol $\mathrm{MS}\left(\times 10^{-8} \mathrm{SI}\right)$

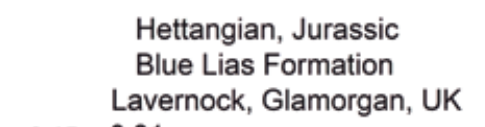

0.15
Hettangian/Sineurian, Jurassic

Blue Lias Formation

Southam Quarry, Warwickshire, UK $0.10]^{0.99 m}$

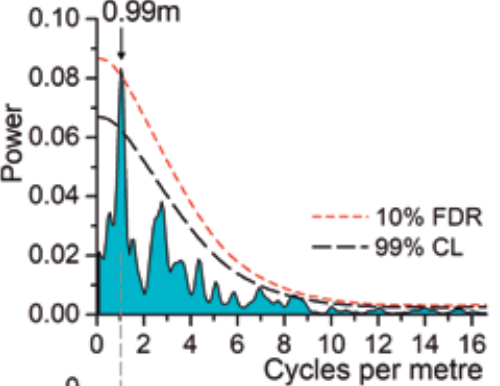

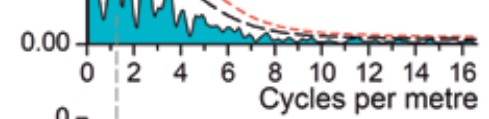
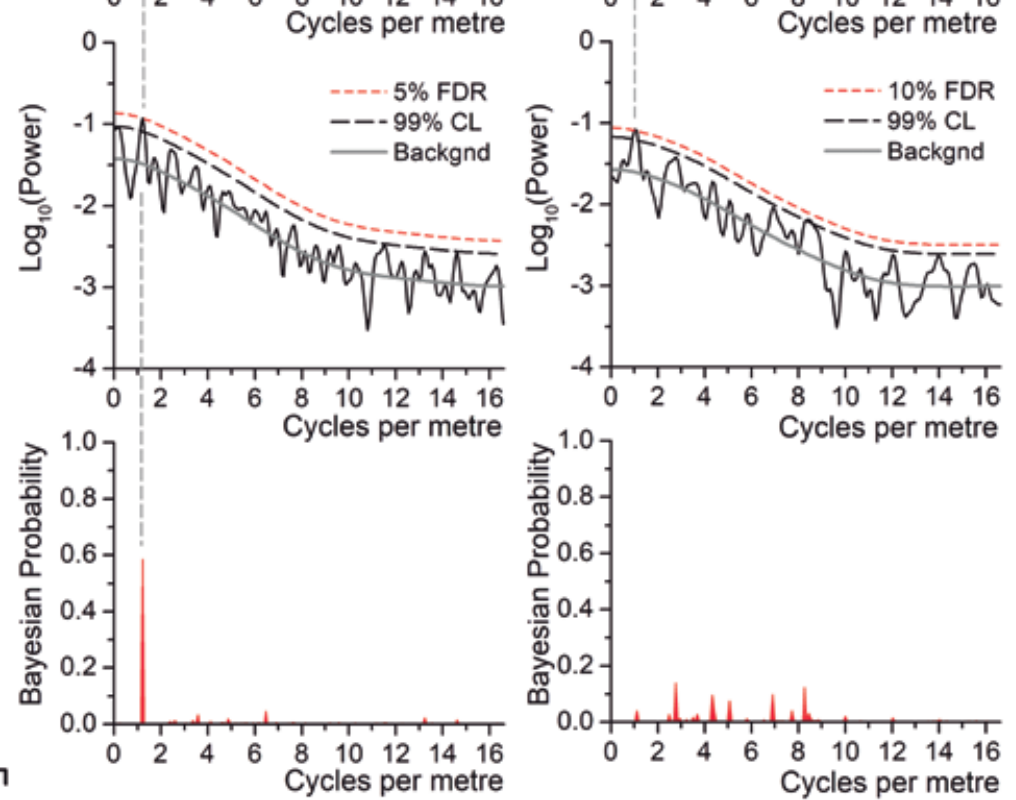

Figure 11. Magnetic susceptibility data, and corresponding power spectra, from the Lower Jurassic Blue Lias Formation (Rhaetian to Sinemurian) at Lavernock, Glamorgan (Figs 2 and 3f) and Southam Quarry, Warwickshire, UK (Fig. 2).

Figura 11. Datos de susceptibilidad magnética, y sus espectros de potencia correspondientes, de la formación Blue Lias del Jurásico Inferior (Rhaetiano a Sinemuriano) en Lavernock, Glamorgan (Figs. 2 y $3 f$ ) y Southam Quarry, Warwickshire, Reino Unido (Fig. 2).

don and Jenkyns, 1999). Longer wavelength cycles of close to $3 \mathrm{~m}$ wavelength were inferred to relate to short eccentricity forcing and the decimetre cycles to precession. The exceptional regularity of the lower two thirds of the Belemnite Marls led to selection of these data to illustrate methods of time-series analysis (Weedon, 2003). Vaughan et al., (2011) confirmed detection of the decimetre scale cyclicity using FAL testing, of both the whole of the unit (despite the previously flagged non-stationarity and aliasing), and of the lower two-thirds of the data.

The power spectrum of $\% \mathrm{CaCO}_{3}$ shows the peak associated with $0.37 \mathrm{~m}$ cycles exceeding the $0.1 \%$ FDR, but there is no associated high Bayesian prob- ability. A small spectral peak corresponding to cycles of $3.28 \mathrm{~m}$ exceeds the $5 \%$ FDR and is close to a power concentration representing the length of the dataset $(16.41 \mathrm{~m})$. The \%TOC data have regular cycles of 0.37 $\mathrm{m}$ with a spectral peak exceeding the $0.05 \%$ FDR and associated with high Bayesian probability (1.00). Metre scale $(2.74 \mathrm{~m})$ cycles are also indicated by a spectral peak exceeding the $5 \%$ FDR.

Although both the $\% \mathrm{CaCO}_{3}$ and \%TOC time series were obtained from the same rock samples the contrast in Bayesian probability is stark. Inspection of the periodograms of the linearly detrended, pre-whitened data (Fig. 10) reveal similar overall concentrations of power at the $1 / 0.37 \mathrm{~m}$ frequency 

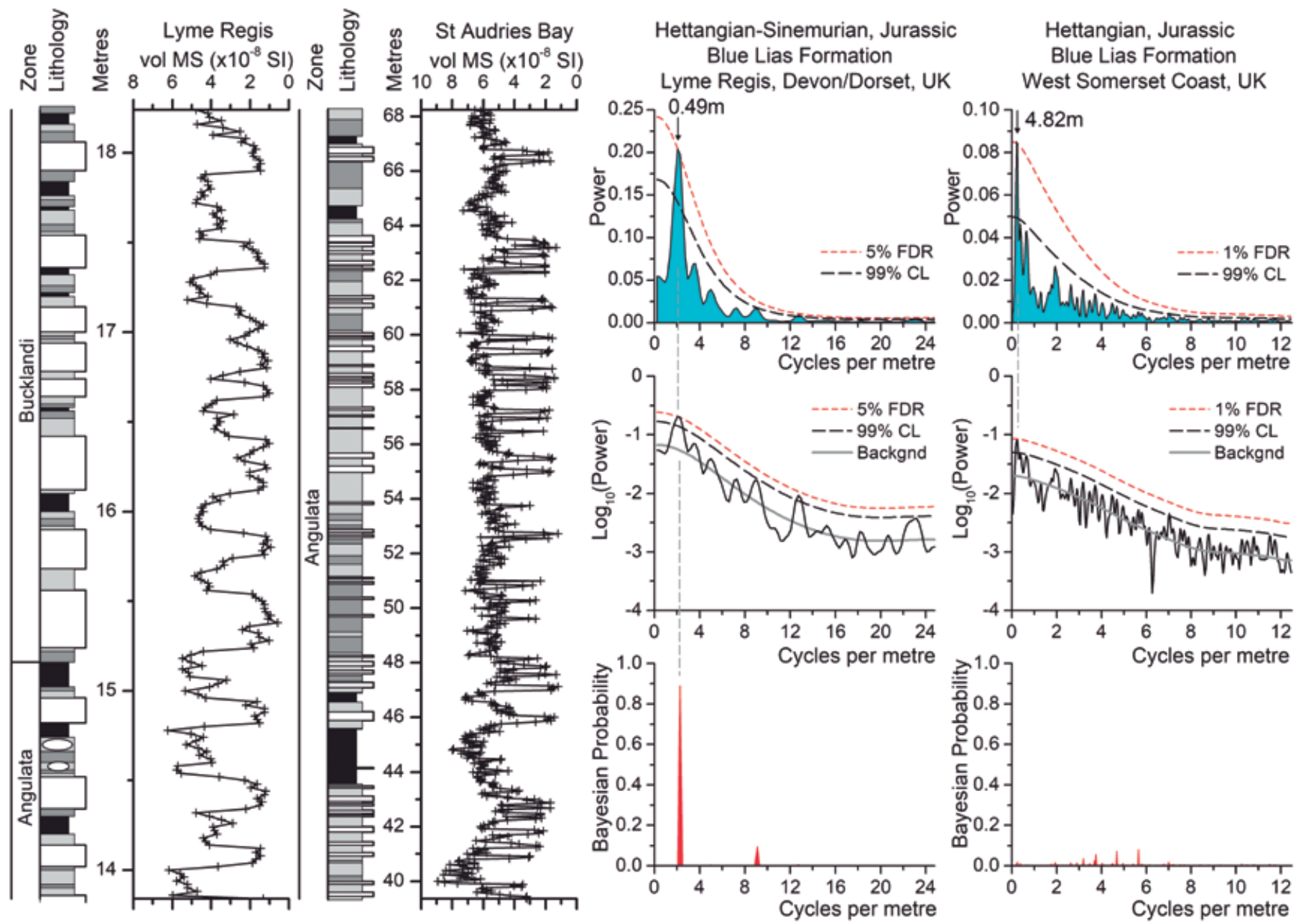

Figure 12. Magnetic susceptibility data, and corresponding power spectra, from the Lower Jurassic Blue Lias Formation (Rhaetian to Sinemurian) at Lyme Regis, Dorset and the West Somerset Coast, UK (Fig. 2).

Figura 12. Datos de susceptibilidad magnética, y sus espectros de potencia correspondientes, de la formación Blue Lias del Jurásico Inferior (Rhaetiano a Sinemuriano) en Lyme Regis, Dorset y West Somerset Coast, Reino Unido (Fig. 2).

for both variables. However, the \%TOC data produce a narrower spectral peak at this frequency. For the $\% \mathrm{CaCO}_{3}$ data the multiple high periodogram estimates near $1 / 0.37 \mathrm{~m}$ means that for each individual estimate defining the peak there is less distinction from the white noise background and, on re-scaling, the probability is far less concentrated. For Fig. 10 note that, to show the small probability increase at the $1 / 0.37 \mathrm{~m}$ scale, the Bayesian probability scale for $\% \mathrm{CaCO}_{3}$ is limited to 0.2 (instead of 1.0 used in Fig. 9). This case shows that data providing strong evidence for regular cyclicity on standard power spectra do not necessarily have large Bayesian probability at the same frequency. Consequently, the absence of high Bayesian probability cannot be interpreted without reference to a power spectrum.

\section{G) Hettangian-Sinemurian stages, Jurassic, UK}

The Blue Lias Formation is well-known for the presence of readily found invertebrate fossils and rare, but famous, marine reptiles (e.g. ichthyosaurs and plesiosaurs, Lord and Davis, 2010) on the coast at Lyme Regis on the Devon/Dorset border of the UK (Figs 2 and 3f). Centimetre- to metre-scale beds of light marl, often with limestone nodules, dark marl and organic-carbon-rich, laminated shale, are interbedded with decimetre-scale limestone beds (Fig. 3f, Weedon et al., 
2018). Detailed lithostratigraphic and biostratigraphic comparison of the exposures on the coasts of West Somerset and Glamorgan and inland at Southam Quarry (Fig. 2) reveal that, despite the hemipelagic setting, there were profound temporal and lateral variations in accumulation rates and the presence of frequent significant hiatuses (Weedon et al., 2018). The formation spans the uppermost Triassic (Rhaetian Stage) and the Hettangian and lower Sinemurian stages of the Jurassic.

House (1985) argued that the cyclicity could be related to Milankovitch cycles. Weedon (1986; 1987) used Walsh power spectra of digitized logs to demonstrate regular cyclicity. Weedon et al. (1999) described MS data from Lyme Regis and argued for a dominant cycle related to obliquity forcing. Weedon et al. (2018; 2019) recently reassessed the MS data from Lyme Regis and the three other sites mentioned (Fig. 2). They introduced the spectral methods adopted here and concluded that, in spite of complications due to the numerous stratigraphic gaps in each section, the main cyclicity was related to short eccentricity cycles with associated spectral peaks exceeding the 5\% FDR at two sites and weaker, shorter and less regular sedimentary cycles linked to obliquity and precession.

Analysis of MS data from each of the four sites is illustrated here. At Lavernock, data from 0.0 to 13.17 $\mathrm{m}$ produce a spectral peak exceeding the $5 \%$ FDR and Bayesian probability of 0.59 at a frequency of $1 / 0.81 \mathrm{~m}$ (Figs $3 f$ and 11). Analysis of data from 0.0 to $17.13 \mathrm{~m}$ by Weedon et al. (2019) produced the same result for the standard spectrum, but the reported high Bayesian probability resulted from analysis of non-pre-whitened data. At Southam Quarry data from 17.67 to $28.56 \mathrm{~m}$ shows a large spectral peak for this Hettangian/Sinemurian interval (Fig. 11). However, the spectral peak associated with cycles of $0.99 \mathrm{~m}$ wavelength only exceeds the $10 \%$ FDR (i.e. below the $5 \%$ level required for accepting cycle detection adopted here).

Upper Hettangian to lower Sinemurian data from 13.84 to $18.24 \mathrm{~m}$ from Lyme Regis (slightly longer than section C of Weedon et al., 2019) are associated with a spectral peak linked to $0.49 \mathrm{~m}$ cycles exceeding the $5 \%$ FDR plus high Bayesian probability $(0.89$, Fig. 12). This contrasts with MS measurements between 39.36 and $68.24 \mathrm{~m}$ (upper section $B$ plus section $C$ of Weedon et al., 2019) from the upper Hettangian of the West Somerset Coast. There is a spectral peak exceeding the 1\% FDR associated with cycles of $4.82 \mathrm{~m}$, but it lacks corresponding elevated Bayesian probability.

Weedon et al. (2019) showed that the limestones of the late Hettangian on the West Somerset Coast related to precession cycles (period of about $20 \mathrm{kyr}$ ), but that the limestone beds in the Hettangian of Lyme
Regis are associated with the short eccentricity cycles (period of about $100 \mathrm{kyr}$ ). In the upper Hettangian and Lower Sinemurian the $0.49 \mathrm{~m}$ cycles at Lyme Regis and the $4.82 \mathrm{~m}$ cycles from the West Somerset Coast are both believed to represent short eccentricity cycles. The contrast in lithostratigraphic expression of limestone beds is explicable in terms of differences in accumulation rates (section 6 of Weedon et al., 2019).

\section{Discussion and conclusions}

\section{A) Data analysis}

To avoid mistakenly forcing noisy data to fit a pre-conceived notion of astronomical forcing of sedimentation, a clear demonstration of at least one scale of regular cyclicity in the depth domain is essential before applying more sophisticated ways of linking the cyclicity to orbital cycles (e.g. Li et al., 2010; Meyers, 2019). Time series from seven lithostratigraphic formations from the Oligocene and the Jurassic have been tested for evidence of regular cyclicity. In all cases the same time series analytical methods have been applied, specifically: linear detrending of time series; the use of the Lomb-Scargle transform to allow spectral estimation without data interpolation, spectral background location using the empirical SWA and allowance for multiple frequency testing using False Discovery Rates. Use of FDR means that the data themselves are employed to find the spectral level at which Type I errors are controlled and Type II errors are minimized (Benjamini and Hochberg, 1995; Miller et al., 2001; cf. Kemp, 2016). These methods have been designed to address the concerns of Vaughan et al. $(2011 ; 2015)$. Consequently, the results reported are considered to provide a rigorous test of the presence of regular cyclicity in the depth domain.

Having applied Bayesian probability spectra to many datasets two useful conclusions have been reached. Firstly, an analysis of non-pre-whitened data, as used by Weedon et al., (2019), yields the expected high probability at the right frequency when power spectral peaks exceed the 5\% FDR. However, the Bayesian analysis of pure AR1 (red noise) without pre-whitening shows that high Bayesian probability can result from the presence of large spectral peaks that are distinct from the white noise null model (Fig. 1). Cyclostratigraphic data characteristically have strong red noise characteristics (high $\rho_{1}$ ). Therefore, pre-whitening of the linearly detrended data is required in order to apply this form of Bayesian analysis meaningfully. Secondly, the case of the Belemnite Marls proves that the lack of high Bayesian probability at the frequency of a significant power spectral 
peak does not necessarily result from a lack of regular cyclicity as detected through appropriately stringent normal power spectral methods (i.e. with unbiased spectral backgrounds and correction of confidence levels for multiple frequency testing). Bayesian probability spectra can provide useful confirmation of regular cycle detection, but it would be unwise to use them without inspection of the associated power spectra.

\section{B) Implications of the results}

In four formations power spectral peaks exceeded the $0.01 \%$ FDR (ODP site 925, Oligocene, Ceara Rise; Boom Clay Formation, Oligocene, Belgium; Rosso Ammonitico Lombardo, Toarcian, Switzerland; Lower Morbio Formation, mid Pliensbachian, Switzerland). The data from one of four sites in the Blue Lias Formation of the Lower Jurassic of the UK (Southam Quarry) had a spectral peak only passing the $10 \%$ FDR. In all other cases the spectra contained at least one peak exceeding the 5\% FDR. Every formation had, for at least one location or variable, high Bayesian probability supporting a standard power-spectral peak exceeding the 5\% FDR.

These results are not consistent with the assertion of Vaughan et al., (2011) that: "almost certainly the vast majority of cycle detections ... in the stratigraphy literature are false". The processing methods employed represent agreement with the improvements to the way regular cycles are detected in cyclostratigraphy as advocated by Vaughan et al., $(2011 ; 2015)$. So why is it that their assertion is not supported? As shown for most cases studied here, if confidence levels that allowed for multiple testing had been added, then at least some of the spectral peaks illustrated would have exceeded the 5\% FDR. Therefore, previously published studies can, in at least some cases, have correctly claimed detection of regular cyclicity in the depth domain despite the statistical methods used being insufficient by current standards. Regardless of the fact that the methods used were deficient in the published literature according to Vaughan et al. $(2011 ; 2015)$, this does not mean that genuinely significant regular cyclicity had not been analysed.

It is worth remembering that the iconic papers on Lower Pleistocene oxygen-isotope time series by Ruddiman (1986; 1987a) and Shackleton et al. (1990) did not illustrate confidence intervals or fitted spectral backgrounds. Nevertheless, the data from sites DSDP 607 and ODP 677 which they studied have exceedingly regular cycles recording obliquity in the depth domain (Fig. 4).
The examples described here prove, in the author's opinion that historically published cyclostratigraphic studies for Palaeogene and Jurassic strata have included sound conclusions. This does not demonstrate that this has always been the case. There is a need for other published data to be re-assessed. For instance, Meyers (2019) showed multi-taper power spectra from the depth domain with False Alarm Levels (FAL) and AR1 backgrounds. In the case of the DSDP 607 benthic foraminifera oxygen isotope data, the interval corresponding to 1.36 to $2.25 \mathrm{Ma}$, yielded a spectral peak exceeding the $5 \%$ FAL. This is consistent with the $>0.01 \%$ FDR result for the 1.21 to $2.60 \mathrm{Ma}$ interval of the same dataset (Fig. 4). At least one spectral peak exceeded the $5 \%$ FAL for data from the Miocene, Eocene andTriassic, but oneTriassic dataset had a spectrum where no spectral peak exceeded this level (Meyers, 2019). Those results and the results reported here support the idea that uniformitarianism applies in cyclostratigraphy when comparing Lower Pleistocene- with pre-Neogene-sections. It will require appropriate reanalysis (e.g. using the criteria adopted here) of many more previously published depth domain studies to more thoroughly test the Vaughan et al. (2010) assertion.

\section{C) Analysis of data sub-sections}

There remains an outstanding issue concerning allowance for multiple testing. This concerns the selection of subsections of data for analysis. Vaughan et al. (2011) took the view that it is valid to generate power spectra for the whole of cyclostratigraphic time series without allowing for non-stationarity. Their analysis of the whole PEF downhole log from the Kimmeridge Clay Formation and the whole of the $\% \mathrm{CaCO}_{3}$ record from the Belemnite Marls ignored previous demonstrations of substantial variations in accumulation rates and in the latter case specifically flagged aliased data at the top of the unit (Weedon and Jenkyns, 1999). Analysis of such non-stationary data is known to degrade the likelihood of detecting regular cyclicity in the depth domain particularly at the highest frequencies (e.g. Weedon, 2003; Huybers and Wunsch, 2004; Kemp, 2016; Martinez et al., 2016) regardless of the use of appropriate spectral methods. Spectral analysis only provides a meaningful description of the variance distribution by frequency if the data analysed are stationary and ergodic (i.e. the single data set can be considered statisticaIly representative of an ensemble, Priestley, 1981).

Therefore, using sub-sections of cyclostratigraphic data to achieve stationarity is both justified and necessary. Li et al. (2018) introduced a procedure to monitor variable sedimentation rates within single 
sections and Weedon et al. (2019) illustrated how high-resolution biostratigraphic correlations between sections can reveal long-term changes in accumulation rates and hiatuses. However, subdivision of the data could be considered to be a form of "data mining" and consequently there should be allowance for the implied multiple testing. Unfortunately, it is not obvious how such allowances should be applied. It will require future work to solve this issue.

Nevertheless, the analysis of the whole of the Belemnite Marls $\% \mathrm{CaCO}_{3}$ record by Vaughan et al. (2011) detected regularity. Furthermore, in the cases of the Rosso Ammonitico Lombardo (Toarcian), the Lower Morbio Formation (mid Pliensbachian) shown in Fig. 8 plus the Upper Morbio Formation (upper Pliensbachian - results not shown) the complete datasets were analysed. In all three cases at least one spectral peak exceeds the $0.01 \%$ FDR. Since these cases do not involve selecting sub-sections, no adjustment for multiple testing is required, and detection of regularity in the depth domain is confirmed.

\section{Acknowledgements}

My thanks to Hugh Jenkyns for supervising my D.Phil. at Oxford and for originally directing me to most of the terrestrially exposed formations that were re-analysed in this paper. Alberto Martinez-de la Torre kindly provided the Spanish translations. Thanks also to David Smith and Stephen Hesselbo for constructive reviews.

\section{References}

Abdi, H. 2007. The Bonferroni and Šidák corrections for multiple comparisons. In: Salkind, N. (ed.), Encyclopedia of Measurement and Statistics, Sage, 103-107.

Abels, H.A., Van Simaeys, S., Hilgen, F.J., De Man, E. and Vandenberghe, N. 2007. Obliquity-dominated glacio-eustatic sea level change in the early Oligocene: evidence from the shallow marine siliciclastic Rupelian stratotype (Boom Formation, Belgium). Terra Nova, 19, 65-73, doi:10.1111/j.1365-3121.2006.00716.x

Barnard, P.C. and Cooper, B.S. 1981. Oils and source rocks of the North Sea area. In: Woodland, A.W. (ed.), Petroleum Geology of the Continental Shelf of North-West Europe, Applied Science Publishers, London, pp. 169-175.

Becker, K., Sakai, H., et al. 1987. Sites 677 and 678. Proceedings of the Ocean Drilling Program, Initial Reports, 111, 253-346, doi: 10.2973/odp.proc.ir.111.104.1988.

Benjamini, Y. and Hochberg, Y. 1995. Controlling the false-discovery rate: A practical and powerful approach to multiple testing. Journal of the Royal Statistical Society, B57, 289-300.
Bernoulli, D. 1964. Zur Geologie des Monte Generoso (Lombardische Alpen). Beiträge zur Geologischen Karte der Schweiz, 118, Kümmerly and Frey, Bern, 134 pp.

Bernoulli, D. and Ulmer, P. 2016. Dropstones in Rosso Ammonitico-facies pelagic sediments of the Southern Alps (southern Switzerland and northern Italy). Swiss Journal of Geosciences, 109, 57-67, doi:10.1007/s00015-0150205-0.

Berra, F., Galli, M.T., Reghellin, F., Torricelli, S. and Fantoni, R. 2009. Stratigraphic evolution of the Triassic-Jurassic succession in the western Southern Alps (Italy): record of the two-stage rifting on the distal passive margin of Adria. Basin Research, 21, 335-353.

Bretthorst, G.L. 1988. Bayesian Spectrum Analysis and Parameter Estimation. Springer, Berlin, 209 pp.

Crampton, J.S., Meyers, S.R., Cooper, R.A., Sadler, P.M., Foote, M. and Harte, D. 2018. Pacing of Paleozoic macroevolutionary rates by Milankovitch grand cycles. Proceedings of the National Academy of Sciences of the United States of America, 115, 5686-5691, doi:10.1073/ pnas.1714342115.

Curry, W.B., Shackleton, N.J., Richter, C. et al. 1995. Leg 154 synthesis. Proceedings of the Ocean Drilling Program Initial Reports, 154, 421-442, doi: 10.2973/odp.proc. ir.154.109.1995.

Gallois, R.W. 2000. The stratigraphy of the Kimmeridge Clay (Upper Jurassic) in the RGGE Project boreholes at Swanworth Quarry and Metherhills, Dorset. Proceedings of the Geologists' Association, 111, 265-280.

Gregory, P. C. 2005. Bayesian Logical Data Analysis for the Physical Sciences. Cambridge University Press, 468 pp.

Hinnov, L.A., Wu, H. and Fang, Q. 2016. Reply to the comment on "Geologic evidence for chaotic behaviour of the planets and its constraints on the third-order eustatic sequences at the end of the Late Paleozoic Ice Age" by Qiang Fang, Huaichun Wu, Linda A. Hinnov. Xiuchun Jing, Xunlian Wang, and Qingchun Jiang [Palaeogeography Palaeoclimatology Palaeoeceology 400 (2015) 848-859]. Palaeogeography, Palaeoclimatology, Palaeoecology, 461, 475-480.

House, M.R. 1985. A new approach to an absolute time scale from measurements of orbital cycles and sedimentary microrhythms. Nature, 313, 17-22.

Hopkins, A.M., Miller, C.J., Connolly, A.J., Genovese, C, Nichol, R.C. and Wasserman, L. 2002. A new source detection algorithm using the false-discovery rate. The Astronomical Journal, 123, 1086-1094.

Huang, C., Hesselbo, S.P. and Hinnov, L. 2010. Astrochronology of the late Kimmeridge Clay (Dorset, England) and implications for Earth system processes. Earth and Planetary Science Letters, 289, 242-255, doi:10.1016/j. epsl.2009.11013.

Huybers, P. and Wunsch, C. 2004. A depth-derived Pleistocene age model: uncertainty estimates, sedimentation 
variability, and nonlinear climate change. Paleoceanography, 19, PA1028, doi: 10.1029/2002PA000857.

Kemp, D.B. 2016. Optimizing significance testing of astronomical forcing in cyclostratigraphy. Paleoceanography, 31, 1516-1531, doi 10.1002/2016PA002963.

Li, M., Kump, L.R., Hinnov, L.A. and Mann, M.E. 2018. Tracking variable sedimentation rates and astronomical forcing in Phanerozoic paleoclimate proxy series with evolutionary correlation coefficients and hypothesis testing. Earth and Planetary Science Letters, 501, 165-179, doi: 10.1016/j.epsl.2018.08.041.

Lord, A.R. and Davis, P.G. 2010. Fossils from the Lower Lias of the Dorset Coast, Palaeontological Association Field Guide to Fossils 13, 444 pp.

Mann, M. E. and Lees, J. M. 1996. Robust estimation of background noise and signal detection in climatic time series. Climatic Change, 33, 409-445.

Martinez, M., Kotov, S., De Vleeschouwer, D., Pas, D. and Pälike, H. 2016. Testing the impact of stratigraphic uncertainty on spectral analyses of sedimentary series. Climates Past, 12, 1765-1783, doi: 10.5194/cp-12-1765-2016.

Meyers, S.R. 2012. Seeing red in cyclic stratigraphy: spectral noise estimation for astrochronology. Paleoceanography, 27, PA3228, doi:10.1029/2012PA002307.

Meyers, S.R. 2019. Cyclostratigraphy and the problem of astrochronologic testing. Earth-Science Reviews, 190, 190-223, doi:10.1016/j.earscirev.2018.11.0155.

Miller, C. J., Genovese, C., Nichol, R. C., Wasserman, L., Connolly, A., Reichart, D., Hopkins, A., Schneider, J. and Moore, A. 2001. Controlling the false-discovery rate in astrophysical data analysis. The Astronomical Journal, 122, 3492-3505.

Morgans-Bell, H.S., Coe, A.L., Hesselbo, S.P., Jenkyns, H.C., Weedon, G.P., Marshall, J.E.A., Tyson, R.V. and Williams, C.L. 2001. Integrated stratigraphy of the Kimmeridge Clay Formation (Upper Jurassic) based on exposures and boreholes in south Dorset, UK. Geological Magazine, 138, 511-539, doi:10.1017/S0016756801005738.

Page, K.N. 2010. Stratigraphical framework. In: Lord, A.R. and Davis, P.G. (ed.), Fossils from the Lower Lias of the Dorset Coast, Palaeontological Association Field Guide to Fossils 13, 33-53.

Päike, H., Frazier, J. and Zachos, J.C. 2003. Extended orbitally forced palaeoclimatic records from the equatorial Atlantic Ceara Rise. Quaternary Science Reviews, 25, 3138-3149.

Press, W. H., Teukolsky, S. A., Vetterling, W.T. and Flannery, B. P. 1992. Numerical Recipes in Fortran, The Art of Scientific Computing. Cambridge University Press, Cambridge, $963 \mathrm{pp}$.

Priestley, M.B. 1981: Spectral analysis and time series. Academic Press, London, 890 pp.

Proistosescu, C., Huybers, P. and Maloof, A. C. 2012. To tune or not to tune: detecting orbital variability in Oligo-Mio- cene climate records. Earth and Planetary Science Letters, 325-326, 100-107, doi:10.1016/j.epsl.2012.01.022.

Ruddiman, W. F., Raymo, M. and Mclntyre, A. 1986. Matuyama 41,000-year cycles: North Atlantic Ocean and northern hemisphere ice sheets. Earth and Planetary Science Letters, 80, 117-129.

Ruddiman, W.F., Kidd, R.B, Thomas, E., et al. 1987b. Introduction, background, and explanatory notes, deep sea drilling project Leg 94, North Atlantic Ocean. Initial Reports of the Deep Sea Drilling Project, 94, 5-19, doi: 10.2973/dsdp.proc.94.101.1987.

Ruddiman, W.F., McIntyre, A. and Raymo, M. 1987a. Paleoenvironmental results from North Atlantic sites 607 and 609. Initial Reports of the Deep Sea Drilling Project, 94, 855-878, doi: 10.2973/dsdp.proc.94.125.1987.

Ruddiman, W.F., Raymo, M.E., Martinson, D.G., Clement, B.M. and Backman, J. 1989. Pleistocene evolution: northern hemisphere ice sheets and North Atlantic Ocean. Paleoceanography, 4, 353-412.

Ruhl, M., Hesselbo, S.P., Hinnov, L., Jenkyns, H.C., Xu, W., Riding, J.B., Storm, M., Minisini, D., Ullmann, C.V. and Leng, M.J. 2016. Astronomical constraints on the duration of the Early Jurassic Pliensbachian Stage and global climatic fluctuations. Earth and Planetary Science Letters, 455, 149-165, doi:10.1016/j.epsl.2016.08.038.

Schwarzacher, W. 1975. Sedimentation models and quantitative stratigraphy. Elsevier, $382 \mathrm{pp}$.

Shackleton, N.J., Berger, A. and Peltier, W.R. 1990. An alternative astronomical calibration of the lower Pleistocene timescale based on ODP site 677. Transactions of the Royal Society of Edinburgh Earth Sciences, 81, 251-261.

Shackleton, N.J., Crowhurst, S.J., Weedon, G.P. and Laskar, J. 1999. Astronomical calibration of Oligocene-Miocene time. Philosophical Transactions of the Royal Society of London, A, 357, 1907-1929.

Vandenberghe, N. 1978. Sedimentology of the Boom Clay (Rupelian) in Belgium. Proceedings of the Koninklijke Akademie voor Wetenschappen België, 40, 1-137.

Van Echelpoel, E. and Weedon, G.P. 1990. Milankovitch cyclicity and the Boom Clay Formation: an Oligocene siliciclastic shelf in Belgium. Geological Magazine, 127, 599-604.

Vaughan, S., Bailey, R.J. and Smith, D.G. 2011. Detecting cycles in stratigraphic data: spectral analysis in the presence of red noise. Paleoceanography, 26, PA4211, doi:10.1029/2011PA002195.

Vaughan, S., Bailey, R.J. and Smith, D.G. 2015. Cyclostratigraphy: data filtering as a source of spurious spectral peaks. In: Smith, D.G., Bailey, R.G., Burgess, P.M. and Fraser, A.J. (ed.) Strata and Time: Probing the Gaps in Our Understanding, 151-157. Special Publications 404 Geological Society, London, doi:10.1144/SP404.11.

Vis, G-J., Verweij, H. and Koenen, M. 2016. The Rupel Clay Member in the Netherlands: towards a comprehensive 
understanding of its geometry and depositional environment. Netherlands Journal of Geosciences, 95, 221251, doi:10.1017/njg.2016.25.

Weedon, G.P. 1986. Hemipelagic shelf sedimentation and climatic cycles: the basal Jurassic (Blue Lias) of South Britain. Earth and Planetary Science Letters, 76, 321-335.

Weedon, G.P. 1987. Palaeoclimatic significance of open-marine cyclic sequences. D. Phil. Thesis (in English) University of Oxford, 2 volumes available at: http://ora.ox.ac.uk/ objects/uuid:aa009e6b-d429-4340-b3c5-30f5227f0148.

Weedon, G.P. 1989. The detection and illustration of regular sedimentary cycles using Walsh power spectra and filtering, with examples from the Lias of Switzerland. Journal of the Geological Society, London, 146, 133-144.

Weedon, G.P., 1997. Data Report. Measurements of magnetic susceptibility for the Oligocene and Lower Miocene of Site 925. Proceedings of the Ocean Drilling Program, Scientific Results, 154, 529-532.

Weedon, G.P., Shackleton, N.J. and Pearson, P.N. 1997. The Oligocene time scale and cyclostratigraphy on the Ceara Rise, western Equatorial Atlantic. Proceedings of the Ocean Drilling Program, Scientific Results, 154, 101-114.

Weedon, G.P. and Jenkyns, H.C. 1999. Cyclostratigraphy and the Early Jurassic time scale: data from the Belemnite Marls, Dorset, southern England. Geological Society of America Bulletin, 111, 1823-1840.

Weedon, G.P., Jenkyns, H.C., Coe, A.L. and Hesselbo, S.P. 1999. Astronomical calibration of the Jurassic timescale from cyclostratigraphy in British mudrock formations. Philosophical Transactions of the Royal Society, London, 357, 1787-1813.
Weedon, G.P., Coe, A.L. and Gallois, R.W. 2004. Cyclostratigraphy, orbital tuning and inferred productivity for the type Kimmeridge Clay (Late Jurassic), Southern England. Journal of the Geological Society, London, 161, 655-666.

Weedon, G.P., Jenkyns, H.C. and Page, K.N. 2018. Combined sea-level and climate controls on limestone formation, hiatuses and ammonite preservation in the Blue Lias Formation, South Britain (uppermost Triassic - Lower Jurassic). Geological Magazine, 155, 1117-1149, doi:10.1017/S001675681600128X.

Weedon, G.P., Page, K.N. and Jenkyns, H.C., 2019. Cyclostratigraphy, stratigraphic gaps and the duration of the Hettangian Stage (Jurassic): insights from the Blue Lias Formation of Southern Britain. Geological Magazine, 156, 1469-1509, doi: 10.1017/S0016756818000808.

Wiedenmayer, F. 1980. Die ammoniten der mediterranen Provinz im Pliensbachian und unteren Toarcian aufgrund neuer Untersuchhungen im Generoso-Becken (Lombardische Alpen). Denkschriften der Schweizerischen Naturforschenden Gesellschaft, 93, Birhäuser, Stuttgart, $260 \mathrm{pp}$.

Winterer, E.L. and Bosellini, A. 1981. Subsidence and sedimentation on Jurassic passive continental margin, Southern Alps, Italy. The American Association of Petroleum Geologists Bulletin, 65, 394-421.

Zachos, J.C., Flower, B.P. and Paul, H. 1997. Orbitally paced climate oscillations across the Oligocene/Miocene boundary. Nature, 388, 567-570.

Zachos, J.C., Shackleton, N.J., Revenaugh, J.S., Pälike, H. and Flower, B.P. 2001. Climate response to orbital forcing across the Oligocene-Miocene boundary. Science, 292, 274-278.

Recibido: julio 2019

Revisado: noviembre 2019

Aceptado: octubre 2019

Publicado: marzo 2021 